\title{
O segundo consenso de Washington e a quase-estagnação da economia brasileira
}

\author{
The second Washington consensus and the \\ quasi-stagnation of the Brazilian economy
}

LUIZ CARLOS BRESSER-PEREIRA*;**

RESUMO: Enquanto nos aspectos éticos e sociais o governo Cardoso (1995-2002) foi bem-sucedido, seus resultados econômicos foram frustrantes. Nesses oito anos, a taxa de investimento não aumentou e a renda per capita diminuiu, enquanto as dívidas pública e estrangeira aumentaram substancialmente. Esse fraco desempenho econômico pode ser explicado por três causas encadeadas: um erro na definição da agenda, a adoção do Segundo Consenso de Washington e a alienação das elites. A decisão de definir a inflação alta como o principal problema a ser enfrentado, em vez de alcançar o equilíbrio em contas estrangeiras, representou um grande erro macroeconômico, o que pode ser explicado pelo Segundo Consenso de Washington. Esse consenso propôs na década de 1990 que os países altamente endividados deveriam crescer contando com a poupança externa, embora essa não seja a experiência entre os países da OCDE. O resultado foi avaliar o real, o aumento artificial dos salários e do consumo, de modo que, em vez de crescimento, aumentamos o endividamento. Por que essa estratégia foi adotada? Os interesses dos países ricos não são difíceis de adivinhar. Por parte do Brasil, a única explicação é a alienação das elites brasileiras em relação ao interesse nacional do país. Como resultado final, o governo Cardoso termina com outra crise na balança de pagamentos.

PALAVRAS-CHAVE: Estagnação; Consenso de Washington; poupança externa; deficit em conta corrente.

ABSTRACT: While in the social and ethical realms the Cardoso administration (1995-2002) was successful, its economic outcomes were frustrating. In these eight years the in- vestment rate did not increase and income per capita growth lagged, while public and foreign debts increased substantially. This poor economic performance may be explained by three chained causes: a mistake in agenda setting, the adoption of the Second Washington Consensus, and the alienation of elites. The decision of setting high inflation as the major problem

\footnotetext{
* Professor da Fundação Getúlio Vargas, São Paulo. E-mail: bresserpereira@gmail.com.

** Trabalho baseado no artigo "Financiamento para o Subdesenvolvimento: O Brasil e o Segundo Consenso de Washington", apresentado na comemoração dos 50 anos do BNDES, outubro de 2002. Revisado em dezembro de 2002.
} 
to be tackled instead of achieving equilibrium in foreign accounts represented a major macroeconomic mistake, which can be explained by the Second Washington Consensus. This consensus proposed in the 1990s that highly indebted countries should grow counting on foreign savings, although this is not the experience among OECD countries. The outcome was to evaluate the real, to increase artificially wages and consumption, so that instead of growth we have been increasing indebtedness. Why this flopped strategy was adopted? Rich countries' interests are not difficult to guess. On the part of Brazil, the only explanation is Brazilian elites' alienation in relation to the country's national interest. As a final outcome, the Cardoso administration ends with another balance of payments crisis.

KEYWORDS: Stagnation; Washington Consensus; foreign savings; current account deficit. JEL Classification: O11; E11.

A atividade empresarial depende diretamente da possibilidade de financiamento. Marx dizia que os juros são o pagamento que os capitalistas ativos fazem aos inativos pelo uso de seu capital. Schumpeter, por sua vez, definia o empresário como aquele que, possuindo crédito, utiliza-o para financiar suas inovações. Basta que a taxa de juros seja menor do que a taxa de lucro esperada para que faça sentido econômico o financiamento do investimento. Tudo isto é bem sabido. O que não é tão evidente, porém, é a relação inversa: o financiamento como causa de subdesenvolvimento. Neste trabalho vou tratar deste tema examinando o financiamento externo do Brasil de um ponto de vista macroeconômico. Não é apenas o financiamento externo que pode ser causa de desastre econômico. Os técnicos do BNDES, como de qualquer banco, certamente já tiveram a experiência de haver realizado um financiamento a uma empresa e este financiamento tê-la levado à ruína. Bastava que o empréstimo financiasse projeto equivocado, que não tivesse a rentabilidade prevista. Ou que a teria, se o projeto houvesse sido bem executado, se uma parte dos recursos emprestados não houvessem sido desperdiçados. Ora, se isto pode acontecer facilmente com empresas, e pode também acontecer com o Estado, quando este se endivida para financiar seus próprios projetos, poderá acontecer também - e argumentarei que isso ocorre com muito mais facilidade — quando se trata de endividamento externo de um país, quando além de empresas se endividarem também a nação se endivida, na medida em que o pagamento dos financiamentos passa a depender não apenas da liquidez das empresas mas também da disponibilidade de divisas do país.

Não vou tratar deste tema num nível puramente teórico porque neste nível há pouco a dizer. O financiamento externo será causa de subdesenvolvimento ao invés de desenvolvimento se os recursos emprestados para um país acabarem sendo principalmente utilizados para consumo e não para investimento. Por isso, além de tratar desse tema no plano teórico, vou examiná-lo a partir da análise da "estratégia de desenvolvimento" seguida pelo governo americano, pelo Fundo Monetário Internacional e pelo Banco Mundial, nos anos 1990, e aceita de forma acrítica pela maioria dos países em desenvolvimento já altamente endividados, inclusive o Brasil. Esta estratégia, que afinal se revelou uma estratégia de subdesenvolvimento, 
afirma que esses países poderiam desenvolver-se com "poupança externa". E tornou-se de tal forma dominante nos anos 1990 que merece ser chamada de Segundo Consenso de Washington.

Este trabalho está dividido em seis seções. Na primeira, mostro como os oito anos do governo Fernando Henrique Cardoso foram frustrantes no plano econômico, enquanto era bem sucedido nos demais setores. $\mathrm{Na}$ segunda, inicio o estudo das causas do mau desempenho econômico pelo erro de agenda: ao invés de definir o desequilíbrio externo como o principal problema a ser enfrentado, o governo continuou a dar prioridade a um problema já basicamente equacionado - o da alta inflação. Por que esta pouca atenção ao desequilíbrio externo? Na terceira seção atribuo este fato ao Segundo Consenso de Washington, e descrevo esta verdadeira receita para o subdesenvolvimento. Mostro, então, quais as condições para que o financiamento externo possa ser favorável ao desenvolvimento - condições estas que não existiam no Brasil. E por que se adotou esta estratégia proposta pelos países ricos, embora não por eles adotada? Na quinta seção atribuo o fato à alienação de nossas elites, que, da mesma forma que reproduzem os padrões de consumo do centro, reproduzem também suas idéias. Finalmente, na sexta seção, examino os desafios econômicos que se apresentam ao Brasil no momento em que escrevo este trabalho. Discuto, especialmente, como um aprofundamento do ajuste fiscal combinado com uma política de juros mais baixos e a manutenção do câmbio no nível atual, depois da depreciação de 2002, poderão evitar o default, e afinal permitir que se alcance o equilíbrio macroeconômico.

\section{PERSPECTIVAS FRUSTRADAS}

Quando Fernando Henrique Cardoso assumiu a presidência da república, em janeiro de 1995, as perspectivas econômicas que se abriam para o país pareciam as melhores possíveis. Através do Plano Real, que ele próprio liderara enquanto ministro da Fazenda, os preços haviam sido estabilizados, e muitos pensaram, inclusive eu próprio, que isto significava que o país, afinal, depois de quinze anos de alta inflação, alcançara a estabilidade macroeconômica, e que, portanto, estava pronto para retomar o crescimento econômico. ${ }^{1}$ Segundo, um partido moderno e social democrático, o PSDB, liderado por políticos competentes e honestos, comprometido com reformas orientadas para o mercado, assumia o poder, e poderia, assim, assegurar ao país, afinal um equilibrado desenvolvimento econômico e social, sem cair nas malhas do velho populismo, nem do novo neoliberalismo que vinha

\footnotetext{
${ }^{1}$ Embora o governo e a imprensa entendam o Plano Real como compreendendo toda a gestão econômica do governo FHC, este é um entendimento incorreto. O Plano Real - que neutralizou a inércia e terminou com a alta inflação no Brasil — foi anunciado em dezembro de 1993, teve início com a medida provisória que, em $1^{\circ}$ de abril de 1994, introduziu a URV (o mecanismo de neutralização da inércia), e completou-se com a reforma monetária, em $1^{\circ}$ de julho de 1994 . Em $1^{\circ}$ de janeiro de 1995 , começa a gestão econômica Pedro Malan, cujos resultados analiso neste trabalho.
} 
do Norte. Entre essas duas alternativas polares, o novo governo surgia como uma esperança.

Em torno do novo presidente formou-se uma ampla coalizão político-social caracterizada pela participação de todas as classes sociais, principalmente da classe média profissional e da capitalista. Por outro lado, o novo governo logrou obter substancial maioria parlamentar na medida em que obteve o apoio de dois partidos de centro-direita — o PFL e o PPS. Logo, era legítimo esperar que a nova coalizão política teria condições de permanecer no poder por muitos anos - um dos seus mais importantes líderes chegou a falar em 20 anos - promovendo o desenvolvimento econômico do país e tornando-o, como o próprio presidente sempre assinalava, menos injusto. Na oposição ficava fundamentalmente o PT, representando os trabalhadores e a classe média profissional sindicalizada.

Quatro anos depois, em meio a uma crise econômica grave que só foi evitada graças ao socorro do FMI, o presidente foi reeleito. Imediatamente em seguida deixou flutuar o câmbio, e o país pareceu voltar em direção ao equilíbrio econômico, e, possivelmente, à retomada do desenvolvimento. Quatro novos anos estão agora quase terminando de passar, e o que vemos? O país novamente em crise de balanço de pagamentos, e novamente socorrido pelo FMI.

Tabela 1: Crescimento do PIB em três décadas

\begin{tabular}{rcc}
\hline Período & PIB & PIB por habitante \\
\hline $1971-1980$ & $8,63 \%$ & $5,72 \%$ \\
$1981-1990$ & $1,57 \%$ & $-0,37 \%$ \\
$1991-2000$ & $2,65 \%$ & $1,11 \%$ \\
\hline
\end{tabular}

Fonte: Ipeadata - www.ipeadata.org.br

Nestes oito anos a taxa média de crescimento do PIB foi de apenas 2,1 por cento ao ano, o que significa um crescimento da renda por habitante em torno de 1 por cento ao ano. O país não se manteve, portanto, estagnado, mas quase-estagnado. Estes resultados não destoaram do mau desempenho de toda a década, como podemos ver pela Tabela 1. Os anos 1970 foram os últimos de crescimento. Nos anos 1980 a economia brasileira estagnou devido à crise da dívida externa e, mais amplamente, à crise do estado desenvolvimentista. A literatura econômica discutiu amplamente esta crise, havendo pouca discordância sobre sua natureza. ${ }^{2}$ Nos anos 1990 a economia brasileira permaneceu quase-estagnada, mas agora não havia uma explicação simples para o fato. Além de semi-estagnada, pela segunda vez em oito anos essa economia enfrenta hoje uma crise de balanço de pagamentos cuja relação com o alto endividamento interno e externo é evidente, não podendo ser atribuída apenas à insegurança dos credores em relação às eleições presidenciais, nem à ten-

\footnotetext{
${ }^{2}$ Eu a estudei em vários trabalhos. Saliento apenas A Crise do Estado (1991b), uma coleção de papers.
} 
dência da economia americana de incorrer em duas recessões seguidas. O que ocorreu? Por que esse desastre econômico? E por que se revela tão difícil eleger o candidato do governo à presidência?

Não se pode falar em fracasso geral do governo Fernando Henrique. Grandes avanços ocorreram na área social e na área política. Embora obviamente o problema da alta concentração da renda não fosse resolvido, jamais os pobres contaram com uma cobertura social tão ampla. Os padrões éticos do governo nunca foram tão altos. A democracia foi respeitada e reafirmada. A popularidade de Fernando Henrique é uma indicação deste fato. ${ }^{3}$ Os eleitores comportam-se de forma aparentemente paradoxal, prezando seu presidente, mas criticando as altas taxas de desemprego que caracterizaram seu governo, e, assim, recusando-se a votar em um candidato que represente a continuidade desse governo. Esse comportamento é apenas aparentemente paradoxal porque o presidente, nestes anos, assumiu a figura presidencial de maneira impecável. Em um cenário internacional difícil, projetou uma imagem de estadista; em um país cheio de problemas e contradições, demonstrou notável dedicação à coisa pública, honestidade, constante preocupação com a justiça, e grande capacidade de conciliação. Por isso, os brasileiros respeitam senão admiram seu presidente. Mas, ao verificar que seus salários não aumentaram, que suas oportunidades de emprego não aumentaram, mas diminuíram, resistem em eleger um candidato que represente a continuidade de seu governo.

A principal crítica que seu governo recebeu reiteradamente da oposição - a de não se preocupar com o social - afinal se revelou falsa. Seu governo foi socialdemocrata, pois, como é típico desse tipo de governo quando chega pela primeira vez ao poder, aumentou a carga tributária e gastou no social. Quando, por exemplo, Portugal e Espanha transitaram para a democracia e foram governados por partidos social-democratas, liderados, respectivamente, por Mário Soares e Felipe Gonzalez, suas cargas tributárias e seus gastos sociais aumentaram significativamente. ${ }^{4}$ Nos oito anos do governo Fernando Henrique a carga tributária cresceu de 28 para 34 por cento do PIB, e grande parte deste excedente foi gasto em programas sociais nas áreas da educação, saúde, renda mínima, assistência social, reforma agrária, assistência aos pequenos produtores rurais. No final de seu governo é preciso reconhecer que, embora o país continue essencialmente injusto, avanços significativos foram realizados na área social. A mortalidade infantil caiu de 48 para 30 por mil nascidos vivos. A taxa de analfabetismo caiu de 19 por cento em 1991 para 13 por cento em 2000. O sistema nacional de avaliação ficará como um marco da educação nacional (ENEN, Provão, etc.). Imagino que a reforma gerencial da gestão pública de 1995-98, da qual participei, será, por sua vez, um marco da administração pública brasileira. No plano político, o presidente revelou-se um democrata no mais alto nível da palavra: respeitoso dos direitos humanos, toleran-

\footnotetext{
${ }^{3}$ Segundo o Datafolha, a avaliação do governo FHC em setembro de 2002 era a seguinte: $26 \%$ de ótimo e bom, $39 \%$ de regular, e $32 \%$ de ruim e péssimo.

${ }^{4}$ Ver Maravall (1993).
} 
te e sempre disposto ao debate e à conciliação. E no plano ético, deu um exemplo para todo o país. Sua mulher, Ruth Cardoso, acompanhou-o em tudo, mas com luz própria, e sua contribuição para o desenvolvimento do terceiro setor e para os organismos de controle social da administração pública é inestimável. É natural, portanto, que um político com qualidades pessoais deste porte termine seu governo respeitado pelo povo - com bons índices de apoio popular.

Seu governo, entretanto, não ficará na história como o grande governo que poderia ter sido porque deixou a desejar no plano gerencial, como a crise da energia de 2001 demonstrou, e principalmente porque fracassou no plano econômico. Não apenas porque não logrou retomar o desenvolvimento: na verdade, não chegou sequer a estabilizar macroeconomicamente o país, de forma que deixa uma herança pesada para o futuro governo em termos de altas dívidas - interna, ou do Estado, e externa, ou do país - e de altos déficits - público ou do Estado, e externo, ou da nação. Dívidas e déficits que se espelham nas mais altas taxas de desemprego que o país já teve.

Em termos de estoque, a dívida externa pública, em setembro de 2002, era de US\$ 122 bilhões e a dívida privada, de US\$ 91 bilhões. Descontadas as reservas de US\$ 38 bilhões, temos uma dívida externa financeira líquida de US\$ 175 bilhões. Dadas as exportações, em 2002, de US\$ 60 bilhões, a relação dívida externa financeira líquida/exportações (que no Brasil é mais significativa do que a relação dívida externa/PIB, dado o relativo fechamento da economia brasileira) está próxima de 3: é cerca do dobro do que seria uma dívida externa prudente. Uma questão que no final de 2002 os analistas econômicos se perguntavam é se o Brasil entraria ou não em moratória (default).

Embora seja indiscutível a fragilidade financeira da economia brasileira, e do erro cometido em 2001, é necessário assinalar que desde a flutuação do câmbio de janeiro de 1999 a situação da economia brasileira vem melhorando: o superávit comercial vem aumentando consistentemente, já se podendo esperar US\$ 9 bilhões de saldo comercial em 2002; o déficit em conta corrente reduziu-se para cerca da metade em relação ao pico de 1998; e o país vem alcançando as metas fiscais do FMI. Portanto, creio que existem bases reais para se evitar o default, mas isto dependerá mais dos credores do que do próprio país. Dependerá, também, de quem for eleito presidente da república, e de suas declarações e atos nos meses que se seguirem.

\section{O ERRO DE AGENDA}

Os maus resultados econômicos do Brasil nos anos 1990, evidenciados pela baixa taxa de crescimento, pelo grande aumento da dívida do Estado e do país ou seja, da dívida pública e da dívida externa - e pelos altos níveis de desemprego, e agora pela nova crise de balanço de pagamentos, podem ser atribuídos a três ordens de fatos inter-relacionados: (1) o equívoco em relação à definição do problema maior a ser enfrentado pelo governo a partir de 1995; (2) o Segundo Con- 
senso de Washington, segundo o qual deveríamos nos desenvolver com apoio na poupança externa; e (3) a falta de consciência nacional de nossas elites, que ao invés de aumentar seu grau de autonomia com a industrialização, diminuíram-no ao buscar reproduzir os padrões de consumo dos países desenvolvidos e particularmente dos Estados Unidos.

Um erro de agenda explica de forma imediata os maus resultados econômicos dos últimos oito anos. O Brasil não conseguiu alcançar a estabilidade macroeconômica e retomar o desenvolvimento, depois de haver, em 1994, sob a liderança de Fernando Henrique Cardoso como ministro da Fazenda, tão brilhantemente logrado estabilizar uma alta inflação que assolava o país desde 1980, porque em seguida adotou uma política de câmbio e de juros equivocada. Porque, depois da valorização ocorrida em seguida ao Plano Real durante o segundo semestre de 1994, foi incapaz de corrigir plenamente esse desequilíbrio na medida em que, mesmo depois de deixar flutuar o câmbio, manteve uma taxa de juros artificialmente alta. Desta forma, enquanto a taxa de câmbio sobrevalorizada promovia o consumo de bens importados e impedia a estabilização de suas contas externas, a taxa de juros elevada impossibilitava tanto que o país retomasse os investimentos quanto alcançasse o equilíbrio fiscal. Em nome do combate à alta inflação, e obedecendo ao convite ou à proposta do Segundo Consenso de Washington de retomar o crescimento através do recurso à poupança externa, o Brasil — aliás, como um grande número de países altamente endividados - deixou de depreciar sua moeda para o nível compatível com seu alto endividamento externo. Ao invés disso, manteve taxas de juros elevadíssimas que inviabilizaram os investimentos internos e fizeram explodir o déficit público e a dívida pública.

A definição da alta inflação como o principal inimigo a ser enfrentado constituiu um grave erro de agenda. Ao invés de entender, como deveria tê-lo feito, que o Plano Real se consumara com a reforma monetária de $1^{\circ}$ de julho de 1994, ou, no máximo, nos seis meses seguintes, pretendeu continuar com ele. Embora essa estratégia pudesse ser politicamente atrativa, era incompetente em termos de política econômica. Ao adotá-la, o governo ignorou que a neutralização da inércia inflacionária operada pelo Plano Real, a eliminação de quase toda indexação de preços, e a abertura comercial que tornara os preços locais dos bens comercializáveis expostos à competição externa, já haviam logrado reduzir a taxa de inflação do país para níveis aceitáveis, de forma que, embora a inflação continuasse a merecer atenção, eram outros os desafios a serem enfrentados. Os dois principais inimigos, agora, a partir do Plano Real, eram o câmbio valorizado e a alta taxa real de juros - irmãos gêmeos, conforme nos ensina a boa teoria macroeconômica.

O câmbio valorizado leva ao aumento do consumo e à diminuição da poupança interna, e, afinal ao desequilíbrio e à crise de balanço de pagamentos; a alta taxa real de juros dificulta os investimentos, promove o desequilíbrio fiscal, e acaba em crise financeira, quando os credores se dão conta que as altas taxas de juros, ao invés de sinal de austeridade monetária, estão ameaçando a capacidade de o Estado honrar sua dívida interna. Tudo isto, porém, foi ignorado, e a equipe eco- 
nômica liderada pelo ministro Pedro Malan manteve o câmbio gravemente sobrevalorizado e a taxa de juros artificialmente alta entre 1995 e 1998.

Em janeiro de 1999, depois de uma longa luta interna dentro do governo, o presidente da República, contrariando seu ministro da Fazenda, decidiu deixar flutuar o câmbio. ${ }^{5} \mathrm{~A}$ decisão corajosa revelou-se sábia. ${ }^{6}$ Depois de uma necessária elevação da taxa de juros, esta começou a ser sistematicamente reduzida pelo novo presidente do Banco Central. Entretanto, em 2001, um pequeno aquecimento da economia brasileira, o início da recessão nos Estados Unidos, e a crise da Argentina, e principalmente a depreciação do câmbio, que chegou a $\mathrm{R} \$ 2,80$ por dólar, levaram o Banco Central, em nome da meta de inflação, a novamente elevar a taxa de juros básica, fazendo-a voltar aos níveis mais elevados do mundo. Mais uma vez o Banco Central do Brasil quebrava a regra de ouro de qualquer política monetária competente - a de estabelecer a taxa de juros mais baixa possível consistente com o equilíbrio macroeconômico. Como a determinação da taxa de juros é a única arma de que contam as autoridades monetárias para atingir suas metas, há sempre uma "boa razão" para elevá-la. Em um momento o objetivo é atrair capitais de curto prazo, noutro, impedir que a economia se aqueça e o déficit em conta corrente aumente em demasia, noutro ainda, a busca de controlar a inflação ainda que esta não seja uma inflação de demanda. No Brasil sempre há uma "boa" razão para aumentar a taxa de juros, sem falar na má razão: beneficiar os rentistas.

Em 2001 a razão principal alegada para elevar a taxa de juros foi o cumprimento da meta inflacionária. A política de metas de inflação, adotada pelo Banco Central em 2000, foi equivocadamente identificada com o êxito da flutuação cambial de janeiro do ano anterior. E tornou-se uma espécie de tabu, ou de unanimidade nacional, que ninguém se sente autorizado a discutir. Coisa semelhante, mas mais grave, aconteceu na Argentina, com o "Plano de Covertibilidad", que se transformou em verdadeiro tabu, com trágicas conseqüências para o país. No nosso caso a proibição de debate não foi tão grave, mas foi grave o suficiente para que, por

\footnotetext{
${ }^{5}$ Desta luta interna participamos Persio Arida, José Serra, Paulo Renato de Souza, e eu próprio. De nós quatro, apenas Arida e Serra participaram da equipe econômica, o primeiro como presidente do Banco Central nos primeiros sete meses, o segundo, como ministro do Planejamento nos primeiros 15 meses do governo. Arida demitiu-se por discordar da política de câmbio, Serra, para ser candidato à prefeitura de São Paulo. Paulo Renato de Souza, como ministro da Educação, e eu, como ministro da Administração Federal e Reforma do Estado, fomos excluídos da equipe econômica. Eu, porém, insisti muitas e muitas vezes com o presidente sobre a necessidade de desvalorizar ou deixar flutuar o real. Formalizei minha posição com uma carta, em novembro de 1996, acompanhada de um pequeno paper, que depois publiquei na Revista de Economia Política, "As Três Formas de Desvalorização Cambial” (1997), no qual não mencionava o Brasil devido à minha condição de ministro do governo.

${ }^{6}$ Surpreendentemente, porém, apenas o presidente do Banco Central perdeu o cargo, enquanto o ministro Pedro Malan foi mantido apesar de ter sido desautorizado pelo presidente. O novo presidente do Banco do Central, Francisco Lopes, que, dentro da equipe econômica apoiara a flutuação do câmbio, permaneceu poucos dias no cargo. Sem o apoio do ministro, e enfrentando as naturais dificuldades que se seguiram à flutuação do câmbio, foi substituído por Armínio Fraga, que permanece no cargo. Todos os economistas citados são originários ou fazem parte do corpo docente da PUC do Rio de Janeiro.
} 
exemplo, nenhum dos principais candidatos à presidência da república em 2002 se dispusesse a criticar a adoção da política de metas. O máximo que se fez - como, aliás, também fizemos eu e Nakano em um documento de grande repercussão, "Uma Estratégia de Desenvolvimento com Estabilidade", tornado público no início de 2002 - foi afirmar que a política de metas deveria levar em consideração um prazo mais longo e desconsiderar flutuações temporárias da taxa de câmbio. ${ }^{7} \mathrm{~A}$ meta relevante de inflação deve ser a de médio e longo prazo, pois acelerações e desacelerações transitórias não exigem mudança na taxa de juros. A taxa real de juros tem que reagir primordialmente ao hiato do produto para controlar a inflação. Quando se introduz a taxa de câmbio nesta função de reação, é preciso distinguir a natureza dos choques externos, e a transitoriedade ou não da variação cambial. Reação de pronto a qualquer apreciação ou depreciação pode resultar em instabilidade desnecessária. ${ }^{8}$

$\mathrm{Na}$ verdade, o Brasil em 2000 não estava pronto para uma política de meta de inflação porque esta só tem sentido quando se parte de uma situação de equilíbrio macroeconômico e se quer evitar que o país perca esse equilíbrio. Ora, este não era o caso do Brasil. A taxa de juros elevadíssima e a taxa de câmbio sobre-avaliada eram indicação clara de que era necessário, primeiro, resolver esses dois problemas gêmeos, e depois consolidar a estabilização macroeconômica através de uma política de meta de inflação. Quando a taxa de câmbio não é de equilíbrio — ou seja, quando não garante a zeragem do déficit em conta corrente, em uma economia que já está altamente endividada no plano externo - a elevação da taxa de câmbio necessária terá, por definição, um efeito inflacionário. ${ }^{9}$ Um efeito inflacionário temporário, desde que a economia permaneça desindexada, e a mudança de preços relativos a favor dos bens comercializáveis não seja anulada pela elevação dos preços não-comercializáveis. Mas é sempre um efeito inflacionário que manteria a política de meta de inflação sob a ameaça de uma espada de Dâmocles.

A política de meta de inflação representou um grande avanço em matéria de política econômica dos países desenvolvidos. Primeiro, porque foi uma opção pragmática. Ao invés de se afirmar, dogmaticamente, que a inflação era sempre causada pelo aumento da oferta de moeda, a causa da inflação ficou mais indefinida, deixando-se maior espaço para as políticas econômicas a serem pragmaticamente adotadas. É verdade que esse pragmatismo começou, em seguida, a ser perdido, quando os economistas dos bancos centrais não resistiram, e se puseram a adotar modelos oficiais para a meta de inflação, nos quais as causas da inflação voltavam

\footnotetext{
${ }^{7}$ Ver Bresser-Pereira e Nakano (2002a). A repercussão do paper na imprensa encontra-se documentada em dossiê especial, em www.bresserpereira.org.br. O documento foi publicado na Revista de Economia Política, 21(3), julho 2002, e nesse número já estão publicados quatro papers comentando principalmente a possibilidade de múltiplos equilíbrios da taxa de juros.

${ }^{8}$ Ver Ball (2000), Taylor (2001).

${ }^{9}$ A taxa de câmbio de equilíbrio não é, por definição, a taxa que zera o déficit em conta corrente, a não ser quando o país já se encontra altamente endividado, e um objetivo central de política macroeconômica passa a ser reduzir os índices de endividamento externo.
} 
a se tornar rígidas. Em segundo lugar, a política de meta de inflação foi um avanço porque a política monetária transformou-se na prática em política de taxa de juros, reconhecendo-se assim, keynesianamente, o caráter exógeno da quantidade moeda e da taxa de juros. ${ }^{10} \mathrm{E}$ também, porque nessa política a curva de Philips de curto prazo, inclinada, foi devidamente restabelecida.

Todos esses méritos da política de meta de inflação, entretanto, não justificavam sua adoção pelo Brasil, em 2000, quando a taxa de câmbio estava ainda evidentemente sobrevalorizada devido à alta taxa de juros. Tanto não justificavam que em 2001 o Banco Central equivocou-se gravemente em desencadear uma guerra contra a alta do câmbio - envolvendo nova elevação da taxa de juros, venda de dólares no mercado financeiro local, e troca de títulos federais não indexados por títulos indexados em dólares - em nome do cumprimento da meta da inflação. Acabou, de qualquer forma, não a cumprindo, ao mesmo tempo em que aumentava a vulnerabilidade do país a uma nova crise de balanço de pagamentos, que aconteceu no ano seguinte (quando também a meta de inflação não foi atingida).

O câmbio valorizado, ao não garantir aos exportadores um câmbio mais compensador, reduzia as exportações, e, ao aumentar os salários da classe média artificialmente, propiciava o aumento do consumo e a diminuição da propensão a poupar. Esta diminuição, que pode ser derivada do conceito contábil de poupança, era confirmada, no plano da teoria keynesiana, pela queda dos investimentos e pela conseqüente não realização da renda potencial que a alta taxa de juros provoca. Como "compensação" perversa a taxa de câmbio artificialmente baixa, além de manter os ricos artificialmente ricos em dólares, reduzia o valor em reais da dívida pública indexada em dólares e sua porcentagem em relação ao PIB — uma medida que os economistas do sistema financeiro privilegiam em suas análises...

No plano monetário, por sua vez, a taxa de juros elevada aumentava a dívida interna do país, e sinalizava para o exterior a insegurança das autoridades monetárias locais quanto à estabilidade da economia brasileira. Esta sinalização, por sua vez, legitimava o alto "risco Brasil" - e, portanto a taxa de juros paga pelos empréstimos do Brasil no exterior. E, o que é mais grave, induzia ao aumento dessa taxa de juros, que passava também a refletir a política de juros do Banco Central do Brasil: se suas autoridades se dispunham a pagar, por seus empréstimos de curto prazo, uma taxa de juros maior do que aquela paga pelos bancos centrais de países com o mesmo nível de classificação de risco pelas agências especializadas, isto significava uma desconfiança interna em relação à capacidade de pagamento do país, que podia ser partilhada pelos credores externos. ${ }^{11}$ No documento Bresser e Nakano (2002a), salientamos a existência desse equilíbrio múltiplo da taxa de juros, e do efeito perverso da alta taxa de juros. Ao afirmarmos que a política de

\footnotetext{
${ }^{10}$ Isto está, por exemplo, bem claro na "regra de Taylor" (1993).

11 O efeito da taxa de juros básica sobre a taxa internacional de juros paga pelo Brasil assim como o equilíbrio perverso em que se encontra a taxa de juros no país foram principalmente contribuições de Nakano para nosso texto comum (2002a).
} 
altas taxas de juros, que o Banco Central do Brasil vem seguindo há muitos anos, tinha, entre outros, o efeito de elevar o "risco Brasil", não estávamos, com isto, dizendo que a fixação da taxa de juros básica pelo Banco Central fosse o único determinante da taxa de juros internacional paga pelo Brasil. É claro que os índices de endividamento público e externo, e de déficit público e déficit em conta corrente que o país apresenta continuam a ser os fatores fundamentais. Mas está claro que ao adotarmos no Brasil uma taxa de juros básica muito alta e estarmos sempre prontos a elevála, estávamos indicando para o sistema financeiro internacional nossa própria desconfiança na economia nacional. Por isso, mostramos naquele trabalho que enquanto a taxa de juros básica (SELIC) paga pelo Banco Central do Brasil era duas a três vezes maior do que as taxas pagas pelos bancos centrais de países com classificação de risco igual, as taxas de juros pagas ao exterior pelas empresas brasileiras eram cerca de dois pontos percentuais mais altas do que as taxas pagas pelas empresas daqueles países. ${ }^{12} \mathrm{O}$ efeito sobre a taxa de juros externa é, portanto, menor do que a diferença relativa das taxas de juros básicas: enquanto estas no Brasil têm variado entre 9 e $12 \%$ ao ano, contra uma taxa de juros paga por países de classificação de risco igual à do Brasil de 4 a 6 por cento reais, o diferencial relativo de taxas de juros externas é bem menor.

Ao tomar a decisão de elevar os juros em 2001, o Banco Central voltou, em nome da estabilidade de preços, a desestabilizar gravemente a economia brasileira. O equilíbrio macroeconômico é dado pelo nível de preços, sem dúvida, mas é dado principalmente pelo equilíbrio intertemporal de suas contas externas. Uma economia está equilibrada macroeconomicamente quando tem taxas de juros suficientemente baixas para poder investir e crescer, e, quando o faz, as exportações crescem proporcionalmente às importações, de forma que se possa manter sob controle a taxa de endividamento externo. A taxa de endividamento externo é medida pela relação dívida externa/PIB, e, no caso do Brasil, onde o coeficiente de exportações é muito baixo, principalmente pela relação dívida externa/exportações.

Graças à intervenção do Banco Central no mercado financeiro em 2001, elevando a taxa de juros, vendendo US $\$ 8$ bilhões no mercado interno, e convertendo US $\$ 20$ bilhões de títulos públicos em títulos indexados em dólares, as autoridades monetárias lograram baixar a taxa de câmbio, que se elevara de cerca $\mathrm{R} \$ 2,40$ no início do ano para 2,80 por dólar em abril. Com isto evitou-se uma pequena e provisória elevação da taxa de inflação. Mas o custo dessa política foi alto, como se verificaria no ano seguinte, quando nova crise cambial ameaçou o país, e só foi mantida sob relativo controle graças a novo acordo com o FMI. Em decorrência da crise a taxa de câmbio, entretanto - que fora mantida baixa artificialmente graças à taxa de juros elevada - voltou a subir, agora para próximo de $\mathrm{R} \$ 4,00$

\footnotetext{
12 É preciso distinguir com clareza a "classificação de risco" de um país, que é feita por agências como a Moody's e a Standard \& Poors, do "risco-país", que é dado simplesmente pela subtração, da taxa de juros paga pelo país no exterior, a taxa de juros paga pelos títulos do Tesouro americano. Enquanto a classificação de risco tem uma certa autonomia ou exogeneidade, o risco-país é totalmente endógeno. Mais do que isto, identifica-se com a taxa de juros paga.
} 
por dólar - era o mercado que cobrava sua conta - embora a taxa de juros continuasse em níveis exorbitantes.

Por que a nova crise cambial? Procurou-se explicar o fato com a "subida" de Lula nas pesquisas eleitorais. Entretanto, o candidato do PT já estava com intenções de voto superiores a 30 por cento muito antes de a crise se desencadear. Na verdade, desde as eleições municipais de outubro de 2000, quando o PT alcançou ampla vitória, principalmente nas grandes cidades, estava claro que a probabilidade de eleição de um candidato de esquerda era muito grande. Por outro lado, antes da crise também ficou claro que, na busca da eleição, Lula moderou suas propostas, eliminando delas qualquer elemento radical. A dificuldade do candidato do governo em avançar nas pesquisas eleitorais pode ter sido um gatilho para desencadear a crise — os mercados financeiros precisam de um gatilho qualquer — mas certamente não foi sua causa. Esta tem que ser procurada na fragilidade financeira internacional do país, que a política equivocada de 2001 deixou novamente exposta aos analistas internacionais. Quando a crise econômica abateu-se sobre a Argentina muita gente observou, corretamente, que o Brasil havia se "descolado" da sorte daquele país com a desvalorização de janeiro de 1999. De fato, isto aconteceu. O Brasil, que seguia um caminho semelhante ao da Argentina, salvou-se de um desastre maior quando deixou flutuar o câmbio. O grande erro da Argentina, naquele momento, foi não nos ter acompanhado. Mas esse descolamento era relativo. Quando o Brasil, nos primeiros meses de 2002, voltou a revelar superávits comerciais decepcionantes - que poderiam ter sido evitados se as autoridades monetárias houvessem sido mais realistas e mais respeitosas do mercado - os analistas dos bancos internacionais voltaram a se lembrar dos prejuízos realizados com a Argentina, e, na primeira oportunidade, iniciaram seu ataque especulativo contra o real. A crise de desconfiança, porém, teria sido facilmente contornada se não fossem as semelhanças entre as duas economias, especialmente os superávits comerciais insuficientes, que apontavam para um futuro default.

O socorro pronto do FMI evitou o pior, mas, ao mesmo tempo, confirmou uma verdade sempre esquecida: os credores internacionais e o próprio FMI só se preocupam e só falam no déficit público e na dívida interna, mas, quando acontece a crise, ela sempre ocorre pelo lado externo, à medida que o déficit em conta corrente e a dívida externa tornam-se, a seu ver, altos demais, e não mais se oferece a perspectiva de alta probabilidade de pagamento, ou, mais precisamente, de continuidade do serviço da dívida. Nesses momentos, nunca é o país devedor quem declara moratória. São os agentes financeiros internacionais que suspendem a rolagem da dívida, e, se não houver intervenção do agente de última instância, o FMI, o default torna-se inevitável. Mesmo no caso do Brasil, em fevereiro de 1987, quando o ministro da Fazenda Dílson Funaro declarou a moratória do país, a iniciativa pode ter parecido ser do Brasil: na verdade, o país não tinha alternativa. Poderia ter sido mais prudente, e declarado uma moratória “branca”, parando de pagar por falta de reservas, mas em qualquer hipótese o default era inevitável, e decorrera do endividamento irresponsável do país, e da conseqüente perda de confiança dos credores. 


\section{O SEGUNDO CONSENSO DE WASHINGTON}

Creio ter deixado claro na seção anterior que o Brasil não alcançou a estabilidade macroeconômica depois de haver alcançado, em 1994, a estabilidade de preços, porque adotou uma agenda equivocada: não colocou como prioridade a estabilização das suas contas externas. Cabe, agora, perguntar o porquê desse erro. Eu poderia responder, simplesmente, que o problema foi de incompetência técnica e emocional dos responsáveis pelas decisões de política econômica. Embora esta explicação seja legítima, à medida que muitas vezes os interesses estão neutralizados, e, não obstante, o formulador de política econômica toma decisões incompetentes, que não levam aos objetivos que ele próprio visa, vou aqui apresentar uma razão mais geral. ${ }^{13}$ Fomos vítimas do que proponho chamar o Segundo Consenso de Washington.

De acordo com o Segundo Consenso de Washington, formulado no início dos anos 1990, países altamente endividados, como o Brasil, poderiam desenvolver-se recorrendo à poupança externa, ou seja, endividando-se ainda mais. É preciso, portanto, não confundi-lo com Consenso de Washington, que resumiu a política americana em relação aos países altamente endividados nos anos 1980. Creio ter sido o primeiro no Brasil a ter desenvolvido uma crítica sistemática das idéias ali presentes. ${ }^{14}$ Este consenso, na forma pela qual foi expresso por John Williamson, em um paper de 1989, consistia de uma série de princípios pregando o ajuste fiscal e reformas orientadas para o mercado, ou no que foi também chamado de 'ajuste estrutural'. ${ }^{15}$ Acabou se tornando um símbolo da política neoliberal daqueles anos, embora não propusesse necessariamente reformas ultraliberais visando reduzir o estado ao mínimo. E, principalmente, porque não incluía a abertura financeira, que Williamson expressamente excluiu do Consenso. ${ }^{16}$ Era, entretanto, "neoliberal” na

\footnotetext{
${ }^{13}$ Ver Bresser-Pereira, 2001. Versão ampliada, em português, está para ser publicada na Revista Brasileira de Economia.

${ }^{14}$ Refiro-me à aula magna no Congresso Anual da ANPEC — Associação Nacional de Pós-Graduação em Economia, em dezembro de 1990, em Brasília. Esta aula foi depois publicada em Pesquisa e Planejamento Econômico (Bresser-Pereira, 1991a). No início de 1999, alguns dias antes de desvalorizar o real, o presidente perguntou-me de quanto deveria ser a desvalorização. Respondi, sem hesitar, que deveria ser de 25 por cento. Várias vezes, mais tarde, Fernando Henrique Cardoso referiu-se a esta conversa, dizendo-me que fora eu aquele que mais seguro se revelara em relação ao problema. Deve-se assinalar, entretanto, que a mudança de posição do presidente deveu-se, em grande parte, ao fato de que um dos diretores do Banco Central, Francisco Lafayette Lopes, proveniente da PUC do Rio de Janeiro, no último trimestre de 1998 mudou sua posição e passou a apoiar a flutuação do câmbio. Para efetivála ele assumiu a presidência do Banco Central, substituindo Gustavo Franco, para ser logo em seguida, diante das dificuldades momentâneas da flutuação, ser substituído por Armínio Fraga.

${ }^{15}$ Ver Williamson (1989). A carga ideológica contra o texto de Williamson foi grandemente exagerada. Williamson não é um ultraliberal, e o consenso que detectou em Washington, não era um consenso ultraliberal, não visava reduzir o estado ao mínimo. Tinha apenas um viés liberal (ou neoliberal na língua inglesa na qual "liberal" significa progressista). O que não impede que houvesse ultraliberais entre os que o adotavam.

${ }^{16}$ Em debate com Williamson, Stanley Fischer sugeriu a inclusão da abertura financeira, e Williamson respondeu que não a considerava necessária nem incluída no consenso.
} 
medida em que havia nele um claro viés pró-mercado. Este viés era compreensível, dado o estatismo e o protecionismo que haviam caracterizado o período anterior. O Brasil, como a maioria dos países em desenvolvimento altamente endividados, necessitava de ajustamento fiscal e de reformas orientadas para o mercado, especialmente de maior abertura comercial. Mas era um consenso perigoso, na medida em que ignorava a importância de um Estado forte no plano administrativo e financeiro para se ter um mercado livre e atuante. Em outras palavras, ignorava que as reformas não deveriam visar enfraquecer o Estado, mas, pelo contrário, fortalecêlo. O Primeiro Consenso de Washington está hoje morto, em parte porque muitas das reformas foram feitas, em parte devido ao seu fracasso em promover o desenvolvimento na América Latina, embora, na verdade, esse fracasso se explique muito mais pelo Segundo Consenso do que pelo primeiro, como procurarei argumentar neste trabalho. De qualquer forma, o apoio popular que os programas de privatização obtinham no início dos anos 1990 desapareceu dez anos depois, em grande parte porque monopólios naturais ou quase-naturais, como a produção hidrelétrica de energia, a distribuição de energia, e os sistemas de telefonia fixa urbana foram objeto de privatização da mesma forma que setores competitivos.

No início dos anos 1990, um outro consenso, que eu proponho chamar de Segundo Consenso de Washington, estava se formando - um consenso que teria efeitos mais devastadores sobre os países em desenvolvimento altamente endividados, inclusive o Brasil, quando comparado ao primeiro consenso. Um consenso estabelecido igualmente em Washington, o qual, entretanto, foi adotado pelas elites da grande maioria dos países em desenvolvimento econômico muito mais prontamente do que o primeiro porque, aparentemente, não implicava em nenhum custo - apenas benefícios. Um consenso que surge depois que o Plano Brady equaciona (não resolve) a crise da dívida dos anos 1980. Um consenso que se forma para explicar e justificar uma nova onda de fluxo de capitais que se dirigiu para os países em desenvolvimento.

O Segundo Consenso de Washington é a dimensão verdadeiramente internacional do primeiro. Ao invés de dizer o que os países em desenvolvimento deveriam fazer para ajustar ou estabilizar suas economias, veio dizer o que devem fazer para crescer, para se desenvolver. A receita era simples: bastaria completar o ajuste fiscal e empreender as reformas neoliberais, e, em função deste bom comportamento, usar a poupança externa em um quadro de total abertura financeira. Ao invés do "desenvolvimento cum dívida" dos anos 70, teríamos agora o "desenvolvimento cum poupança externa". Para obter esta poupança era necessário completar as reformas orientadas para o mercado com a abertura financeira.

Sobre o tema da abertura financeira e dos fluxos de capital desenvolveu-se um amplo debate entre os economistas dos países desenvolvidos - alguns críticos da liberalização, outros, entusiastas. Estes partiam do pressuposto neoclássico de que toda liberalização é benéfica, afirmavam que a liberalização financeira é tão necessária para o desenvolvimento quanto a liberalização comercial, e deve ocorrer ao mesmo tempo. Entre os trabalhos críticos, um dos mais significativos foi o de Rodrik, que demonstrou não haver evidência de que países sem controles de capi- 
tais cresçam mais. ${ }^{17}$ Esta literatura é muito interessante, mas não deve ser confundida com a crítica ao Segundo Consenso de Washington. A crítica à abertura financeira concentra-se principalmente no problema da instabilidade financeira internacional causada por fluxos de capital descontrolados, enquanto que a crítica ao Segundo Consenso de Washington que estou aqui propondo é a crítica a uma idéia mais geral - a de que os países já endividados possam desenvolver suas economias com base em poupança externa. O Segundo Consenso de Washington pressupõe e faz o elogio da abertura financeira de forma que sua crítica implica não aceitar esse tipo de liberalização, mas essa crítica é mais ampla, porque põe em causa a idéia até hoje não desafiada de que poupança externa seja a forma adequada de financiar o desenvolvimento.

A estratégia de desenvolvimento econômico do Segundo Consenso de Washington tinha (e tem ainda) um enunciado simples e claro - e aparentemente razoável - como toda ideologia bem sucedida. Pode ser resumida em uma frase que todos nós, cidadãos dos países em desenvolvimento ouvimos dezenas de vezes:

"Nós entendemos que vocês não têm mais recursos para financiar seu desenvolvimento, mas não se preocupem, façam o ajuste fiscal e as reformas, que nós financiaremos seu desenvolvimento com poupança externa, se possível com investimentos diretos". ${ }^{18}$

A sentença compõe-se, portanto, de três termos. O primeiro termo, ou a premissa, "nós compreendemos que vocês não têm mais recursos para financiar seu desenvolvimento", é falso, embora tivesse aparência de verdade, dado o alto endividamento externo dos países. É óbvio que um país como o Brasil, ou como o México, ou como a China, têm recursos para se desenvolver. Mesmo depois de substituir uma parte da poupança interna por poupança externa, em decorrência do Segundo Consenso de Washington, quatro-quintos dos investimentos continuam a ser financiados por poupanças domésticas. O Brasil, como os demais, não conta com "todos" os recursos necessários ou, mais precisamente, desejáveis para financiar seu desenvolvimento. Mas quem os tem? É, porém, um país que já realizou sua acumulação primitiva e sua revolução capitalista, de forma que já dispõe de um Estado e de uma classe de empresários capazes de canalizar, através do sistema financeiro, poupanças para o investimento.

O segundo termo, ou as duas condições, "mas não se preocupem, façam o ajuste fiscal e as reformas", era o mais razoável dos três termos, embora já vimos que pode envolver prejuízos para os países. A primeira condição, a de completar o ajuste fiscal, ou de superar a crise fiscal, era correta: era e continua sendo para

\footnotetext{
${ }^{17}$ Ver Rodrik (1998: 61).

${ }^{18}$ Sobre a estratégia de crescimento com poupança externa ver Bresser-Pereira e Nakano (2002b). De um modo geral, as teorias que aparecem no presente trabalho foram mais extensamente desenvolvidas naquele paper.
} 
o Brasil uma condição para a reconstrução do Estado. As reformas orientadas para o mercado eram também bem-vindas, desde que sensatas ao invés de pura ideologia ultraliberal. Era sensato, por exemplo, abrir mais as economias dos países em desenvolvimento, reduzindo o alto grau de protecionismo que caracterizara o período de substituição de importações; era sensato privatizar setores competitivos ou razoavelmente competitivos; era sensato modernizar a administração pública, substituindo gradualmente a administração pública burocrática por uma administração pública gerencial; era sensato eliminar privilégios no campo da previdência social. Não era sensato, entretanto, privatizar monopólios naturais, nem privatizar empresas que se beneficiassem de altas rendas ricardianas devido a um problema de monopólio natural (o caso, por exemplo, das usinas hidrelétricas), nem fazia sentido privatizar uma atividade como a da previdência básica, que é obrigação de um Estado democrático porque corresponde a um direito social. Os países desenvolvidos não fizeram tais loucuras - deixaram-nas por conta de alguns dos países em desenvolvimento - seguindo um velho princípio: façam o que eu digo, mas não o que eu faço. O Brasil não privatizou a previdência básica, mas privatizou monopólios naturais ou quase-naturais, e indústrias beneficiárias de rendas ricardianas.

No entanto, o erro mais grave do Segundo Consenso de Washington está no seu terceiro termo, na sua conclusão. Cumpridas as duas condições, conclui o consenso "que nós financiaremos seu desenvolvimento com poupança externa, se possível com investimento direto". Aí estava a armadilha que levou a maioria dos países em desenvolvimento já altamente endividados no final dos anos 1980 a pouco crescerem nos anos 1990; aí está a origem das crises de balanço de pagamentos cujo caso limite foi o da Argentina; aí está uma causa básica da equivocada decisão brasileira de desconsiderar o problema do desequilíbrio externo em seguida ao Plano Real; aí está a explicação principal para o fato de o Brasil haver entrado em duas crises de balanço de pagamentos: uma em 1998, no final do primeiro quadriênio do governo Fernando Henrique Cardoso, a outra em 2002, no final do segundo quadriênio.

A política de crescimento com poupança externa contraria grande parte da experiência internacional. Existe a clássica exceção dos Estados Unidos no século XIX, mas, de um modo geral, as pesquisas realizadas entre os países da OCDE, a partir do paper original de Feldstein e Horioka, mostram que, embora esses países recebam e façam investimentos diretos entre si, quase em cem por cento da acumulação de capital neles realizada é resultado de poupança nacional. ${ }^{19} \mathrm{Em}$ um primeiro momento os economistas neoclássicos, presos a seus preconceitos sobre a mobilidade dos capitais, definiram os resultados como um quebra-cabeça - o "FeldsteinHorioka puzzle". Entretanto, estudos posteriores demonstraram que não se tratava de um quebra-cabeças, mas de um simples problema de restrição de solvência (solvency constraint) de cada país. Quer dizer, os países da OCDE não se

${ }^{19}$ Ver Feldstein e Horioka (1980) e toda a literatura que esse paper provocou. 
dispõem a se endividar para investir, ou se endividam limitadamente. Por isso os investimentos são financiados fundamentalmente por poupança nacional. ${ }^{20}$

De acordo com o segundo consenso, o financiamento seria feito com "poupança externa, se possível com investimentos diretos". A dívida patrimonial decorrente do investimento direto não conta no cálculo dos índices de endividamento, dada sua menor liquidez. Não há dúvida, portanto, que se o investimento direto vier, de fato, financiar a acumulação de capital em plantas e equipamentos, excelente. Se, entretanto, o investimento vier para financiar consumo, já que a alta taxa de juros desestimula o investimento real do próprio investidor estrangeiro ou do capitalista nacional que vende sua empresa, esse financiamento apenas agrava a situação do país. Nos países ricos, o investimento direto não é recebido para financiar déficits em conta corrente, mas para que aproveitem mutuamente as vantagens tecnológicas das empresas multinacionais. O Brasil, porém, ao contrário dos países desenvolvidos, tem usado os investimentos diretos e os empréstimos, de acordo com o Segundo Consenso de Washington, para financiar déficit em conta corrente, e, em conseqüência, para aumentar o consumo. Da mesma forma que muitas das reformas que os países ricos aconselharam aos em desenvolvimento, como as reformas privatizando a previdência básica, não foram por eles próprios adotadas, também no caso do financiamento dos seus investimentos eles não seguem os conselhos insistentemente dados aos países intermediários. É a velha história — "faça o que eu digo, não o que eu faço" - que se repete. Os países ricos sabem que a poupança externa que vem com os financiamentos e investimentos diretos sai na forma de consumo na medida em que a taxa de câmbio é artificialmente apreciada. Sabem também quais são as suas restrições de solvência.

Durante o governo Fernando Henrique Cardoso os investimentos direitos aumentaram extraordinariamente: até 1994 o país recebia no máximo 2 bilhões de dólares por ano de investimentos estrangeiros; depois do Real o país passou a receber, em média, 2 bilhões de dólares por mês em investimentos diretos. Mas, contrariando o saber convencional, a taxa de formação de capital não aumentou e a taxa de crescimento da renda por habitante permaneceu em torno de 1 por cento per capita. Durante os anos 1990, a produtividade aumentou extraordinariamente graças - principalmente - à abertura comercial, mas a política macroeconômica baseada em altas taxas de juros e em câmbio relativamente valorizado, impediu que o aumento da produtividade se transformasse em crescimento da renda por habitante. Por outro lado, as altas taxas de juros continuaram desestimulando o investimento real. Desta forma o aumento do endividamento externo patrimonial provocado pelo aumento dos investimentos diretos não teve como contrapartida aumento da acumulação de capital.

A explicação para isto está no fato de que existe um mecanismo perverso que

\footnotetext{
${ }^{20}$ Ver Rocha e Zerbini (2002) para uma survey da evidência. Os autores citam os estudos de Sinn (1992) e Coakley et al. (1996) como evidências adicionais, além das do seu próprio estudo, de que a correlação Feldstein-Horioka não é um quebra-cabeça mas exprime apenas uma solvency constraint.
} 
transforma os financiamentos, inclusive os investimentos diretos das empresas multinacionais, em consumo. Esse mecanismo não é inevitável, mas, se não houver uma plena consciência dele, e políticas macroeconômicas adequadas para neutralizá-lo, os resultados poderão ser desastrosos, como têm sido no Brasil. O mecanismo é simples, e nada tem a ver com as próprias empresas, mas com a política macroeconômica do governo. O investimento direto é um fluxo financeiro adicional para dentro do país que, mantida a taxa de juros, baixa a taxa de câmbio da economia, apreciando a moeda local. Com a valorização aumentam, por definição, os salários, já que a apreciação do câmbio é uma mudança de preços relativos a favor dos bens e serviços não comercializáveis, entre os quais o mais importante é a força de trabalho. Aumentando os salários em função da apreciação da moeda local, aumenta o consumo, diminuindo, proporcionalmente, a poupança nacional. Foi o que aconteceu no Brasil: nos últimos anos o nível de investimentos cresceu muito pouco, enquanto que a poupança doméstica caía proporcionalmente ao déficit em conta corrente.

Está, portanto, embutido no Segundo Consenso de Washington um elemento de valorização artificial da taxa de câmbio: quanto maiores os financiamentos ou os investimentos diretos, que aumentam o endividamento financeiro e patrimonial do país, mais apreciada tende a se tornar a taxa de câmbio, menos estimuladas as exportações ou a substituição competitiva de importações, maior (artificialmente) o poder aquisitivo dos assalariados e maior seu consumo, e, portanto, menor a poupança interna, compensando-se, assim, a entrada da poupança externa com a diminuição da interna, e mantendo-se no mesmo nível o déficit em conta corrente, ou seja, a necessidade de novos financiamentos.

Mesmo que o investimento da multinacional tenha sido feito em prédios e equipamentos, a poupança externa embutida no investimento direto foi anulada pela redução da poupança interna causada pelo aumento do consumo. Como o investimento direto financiou o déficit em conta corrente, o país absorveu poupança externa, ou seja, endividou-se, mas não cresceu, nem aumentou sua capacidade de remunerar o capital estrangeiro investido.

O novo consenso interessava fundamentalmente os bancos comerciais e os bancos do investimento nos países ricos, nos quais o excesso de capitais ou de poupanças que buscam novos mercados lucrativos é uma constante. Interessava mais amplamente os países ricos, cuja política comercial é sempre de aumentar saldos comerciais. E contou, naturalmente, com o apoio das duas instituições financeiras internacionais sediadas em Washington: o FMI e o Banco Mundial.

Como o FMI compatibilizava o caráter frouxo do Segundo Consenso de Washington com sua política macroeconômica supostamente dura? Fundamentalmente, através da estratégia de concentrar toda a sua atenção nas contas fiscais do país, deixando de lado as contas externas. Se examinarmos os acordos firmados pelo FMI nos anos 1990, verificaremos que o déficit em conta corrente está sempre em segundo plano. Mal é mencionado. Se o fosse, e o FMI estabelecesse metas rígidas para o saldo comercial e a conta corrente, não teríamos o Segundo Consenso de Washington. Concentrando-se no déficit público, o FMI continuava a merecer 
sua fama de "duro", embora, no plano externo, estivesse sendo "frouxo". E justificava teoricamente essa política com a teoria dos déficits gêmeos: se o país controlava o déficit público estaria automaticamente controlando o déficit em conta corrente. Ora, sabemos que essa teoria só faz sentido quando a taxa de câmbio é de equilíbrio. Quando ela está valorizada, como tem sido o caso do Brasil desde 1994, o país pode ter déficits públicos relativamente pequenos (senão superávits) e grandes déficits em conta corrente. $\mathrm{E}$, certamente, a economia pode estar desaquecida, e, não obstante, manifestam-se os dois déficits.

Fique claro que a poupança externa que um país recebe é, por definição, déficit em conta corrente. Mantidas as reservas constantes, é aumento de endividamento internacional, seja na forma de dívida financeira, seja na forma de dívida patrimonial representada pelo estoque de capital estrangeiro. O que dizia - e ainda diz - o Segundo Consenso de Washington, portanto, é que era legítimo que países já altamente endividados se endividassem ainda mais, desde que cumprissem os requisitos do Primeiro Consenso: ajuste fiscal e reformas orientadas para o mercado. ${ }^{21}$

\section{FINANCIAMENTO PARA O SUBDESENVOLVIMENTO}

Por que haveria aí um erro de estratégia do ponto de vista do desenvolvimento dos países altamente endividados? Por que uma certa apreciação do câmbio seria perversa? Por que estaríamos, nesse caso, diante de um típico financiamento para o subdesenvolvimento?

Em primeiro lugar, porque há um limite para o endividamento de um país. A partir de um certo limiar torna-se crescentemente perigoso continuar se endividando, principalmente em termos financeiros, mas também, ainda que em menor grau, em termos patrimoniais. Nos anos 1970, quando foi ministro da Fazenda, Mario Henrique Simonsen costumava dizer que o índice dívida externa/exportação não deveria superar 2. Alguns anos mais tarde, em seu livro-texto de macroeconomia, Simonsen foi mais preciso, mas menos severo: um país devedor com um índice dívida externa/PIB inferior a 2 estaria em uma situação confortável; entre 2 e 4 sua situação seria duvidosa; acima de quatro, crítica. ${ }^{22}$

Pesquisas recentes confirmaram a primeira intuição de Simonsen. Embora seja impossível defini-lo com precisão, as pesquisas empíricas confirmam que há um limiar acima do qual a dívida se torna negativa para o país. O Banco Mundial definiu esse limiar pelo índice dívida/exportações, que não deveria ultrapassar 2,2, e pela relação dívida/PIB, que seria de $80 \%$. A maioria dos episódios de crise de

\footnotetext{
${ }^{21}$ Vale observar que toda esta argumentação não leva à conclusão de que qualquer forma de poupança externa seja prejudicial ao país. Desde que a poupança externa venha na forma de investimento direto em bens comercializáveis, será bem-vinda. O essencial, para o país, é reduzir seus índices de endividamento. Esse tipo de poupança pode contribuir nessa direção.
}

${ }^{22}$ Ver Simonsen e Cysne (1995). 
dívida ocorreu quando um desses dois limiares foi ultrapassado. No caso do Brasil, que é um país relativamente fechado para o exterior (seu índice de exportações sobre o PIB continua em torno de 10\%), o índice dívida externa/exportações é claramente o índice crítico. Cohen foi mais estrito. Segundo ele, quando o índice de endividamento supera 2 ou a porcentagem dívida externa/PIB supera $50 \%$, a probabilidade de reestruturação da dívida torna-se alta e o efeito negativo sobre o crescimento torna-se significativo. ${ }^{23}$ Finalmente, um estudo recente de três economistas do FMI demonstra que, a partir do índice de endividamento 1,6-1,7 e de $35-40 \%$ do PIB "o impacto médio da dívida sobre o crescimento da renda por habitante parece se tornar negativo". O estudo também mostra que quando a relação dívida-exportação aumenta de 1 para 3, a taxa de crescimento declina 2 pontos percentuais por ano. ${ }^{24}$

No caso do Brasil, o índice de endividamento dívida externa/exportações era superior a 3 no início dos anos 1990. Uma política de crescimento com poupança externa era, portanto, altamente desaconselhável apenas por essa razão. Hoje este índice já é 4 , não obstante uma parte considerável do endividamento ocorrido na década tenha sido feito através de investimentos diretos, que aumentam a dívida patrimonial mas não influenciam os índices de endividamento financeiro. $\mathrm{O}$ fato de parte da poupança externa ter vindo na forma de investimentos diretos é, por um lado, favorável para o país na medida em que a liquidez desse tipo de dívida é menor. Mas é, por outro lado, negativa na medida em que esses investimentos não considerados nos índices de endividamento externo envolvem, não obstante, o pagamento de serviços ao exterior.

Em segundo lugar, atendida a condição de não ultrapassar o limiar de endividamento externo, o financiamento com poupança externa poderá ser favorável desde que o endividamento correspondente não provoque valorização do câmbio. A valorização, entretanto, tenderá a ocorrer no mercado já que, em princípio, a taxa de câmbio de equilíbrio é inferior à taxa de câmbio de equilíbrio com zero de déficit em conta corrente, quando se admite ser aquele equilíbrio compatível com um déficit em conta corrente. Para impedir tal valorização, que provocará a elevação artificial dos salários e, em conseqüência, do consumo, a solução seria reduzir compensatoriamente a taxa de juros. Isto, entretanto, não foi considerado pela política econômica adotada pelo Brasil. Ainda que houvesse baixa de taxa de juros real em relação às taxas altíssimas do período anterior a 1994, quando prevalecia a alta inflação, a taxa de câmbio manteve-se valorizada, os salários elevados artificialmente, o consumo igualmente elevado, e a taxa de poupança interna rebaixada.

De fato, o que ocorreu no Brasil após 1994 foi que os substanciais déficits em conta corrente, ou seja, a poupança externa aplicada no país, parte da qual em investimentos diretos, foi compensada pela diminuição da poupança interna, de

\footnotetext{
${ }^{23}$ Ver Cohen (1993).

${ }^{24}$ Ver Pattillo, Poirsin e Ricci (2002).
} 
forma que os investimentos totais não aumentaram no período, pelo contrário, diminuíram, e, como já vimos, o desenvolvimento não foi retomado.

Gráfico 1: Taxas de Investimento (1), de Poupança Doméstica (2) e Taxa de Investimento Estrangeiro Direto (\% sobre PIB; (1) - (2) = Taxa de Poupança Externa)

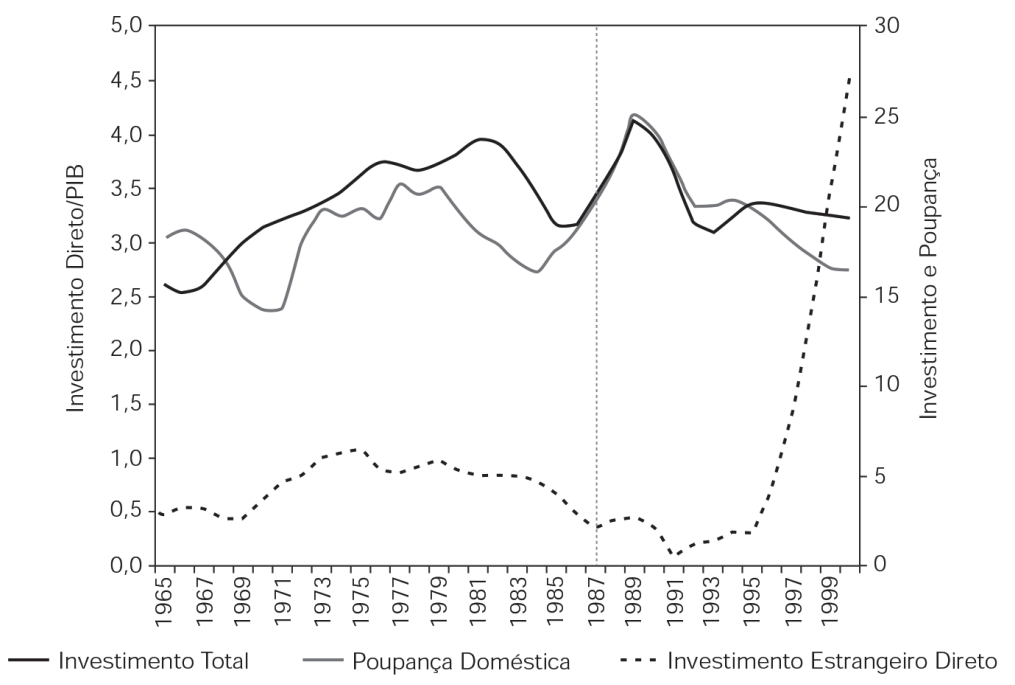

Fonte: FIBGE e Banco Central do Brasil.

O Gráfico 1 é muito expressivo a esse respeito. A poupança externa é a diferença entre a curva de investimento total e a curva de poupança externa, ambas medidas na escala da direita. Vemos, por ele, que a poupança externa, que estava zerada entre 1988 e 1992, e mesmo negativa entre 1993 e 1994 (o que significa que estávamos pagando dívida), torna-se positiva a partir de 1995. Ou seja, passamos a ter déficits em conta corrente, que são crescentes até 1999. A partir daí estabilizam-se e, em seguida passam a diminuir (o que o gráfico já não mostra). Não obstante o aumento da poupança externa, os investimentos totais não aumentam. Pelo contrário, diminuem um pouco na medida em que a poupança doméstica diminui devido ao aumento artificial dos salários causado pela valorização do câmbio. Vemos também que os investimentos totais não aumentam apesar da grande elevação dos investimentos diretos, medidos na escala da direita. Houve, portanto, uma completa e perversa compensação do aumento da poupança externa pela diminuição da interna.

Existe ainda uma terceira condição para que o financiamento externo, ou a poupança externa promova o desenvolvimento do país: que este, ao receber o financiamento, esteja envolvido em um forte processo de desenvolvimento, e, portanto, esteja executando um grande número de investimentos privados e possivelmente estatais com taxas de lucro previstas substancialmente maiores do que a taxa de juros de mercado. Nos anos 1970 era isto o que ocorria. Por isso podemos 
ver no Gráfico 1 que a poupança externa foi sempre positiva nesse período, ou seja, o país se endividava, mas, em compensação, aumentava a taxa de investimento. De acordo, porém, com o Segundo Consenso de Washington, não importava que esses países, além de endividados externamente, não tivessem projetos de investimento. $\mathrm{O}$ "mercado", transformado em um estranho agente social, encarregar-se-ia de criar as condições para os investidores externos formularem e executarem os projetos de desenvolvimento.

Ignorava-se, assim que a teoria econômica nos ensina que um déficit em conta corrente crônico está sempre associado a um câmbio valorizado. Ignorava-se, também, que a valorização do câmbio é uma forma artificial de elevar salários, e, em conseqüência, de aumentar o consumo, principalmente da classe média e da classe rica, cujo consumo tem significativo componente importado. Ignoravam-se ambas as coisas, enquanto o Brasil incorria em enormes déficits em conta corrente e aumentava de forma irresponsável seu endividamento externo nos anos 1990.

Observe-se que não estou negando que a poupança externa possa ser útil a um país. Entretanto, ela só o será se as três condições que estabelecemos acima forem atendidas. Ou seja, que o país não tenha ultrapassado o limiar de endividamento, que não permita a valorização do câmbio e o decorrente aumento do consumo, e que existam amplas oportunidades de investimento produtivo. Nenhuma das três condições estava presente no Brasil, nos anos 1990. Por isso, o recurso à poupança externa só representou endividamento - foi um caso típico de endividamento para o subdesenvolvimento.

O que tivemos nos anos 1990, com o Segundo Consenso de Washington, foi uma política de populismo cambial com apoio do FMI e do Banco Mundial. Há duas formas de populismo econômico, o fiscal (gastar mais do que se arrecada) e o cambial (valorizar o câmbio). Canitrot deixou este assunto claríssimo em seu clássico paper de $1975 .{ }^{25} \mathrm{~A}$ primeira forma é mais óbvia do que a segunda, ambas são desastrosas, mas a segunda é mais perigosa na medida em que as crises dos países em desenvolvimento começam sempre por uma crise cambial. Crises de balanço de pagamentos podem também ocorrer em função de grandes déficits públicos e do descontrole monetário, mas isto só ocorrerá se o país estiver vivendo um período de boom econômico, e, portanto, de excesso de demanda. Ora, desde os anos 1970 o Brasil, como a maioria dos países latino-americanos, não têm essa experiência.

Mas, poderia perguntar alguém, demonstrando uma certa ingenuidade, poupança externa recebida por um país não é sinônimo de investimentos diretos estrangeiros? Por que, então, relacioná-la com populismo cambial? Em primeiro lugar, porque poupança externa é sinônimo de déficit em conta corrente; só é sinônimo de investimento direto estrangeiro para quem não conhece as contas do balanço de pagamentos. Mas, poderia continuar o perguntador ingênuo, se contabilmente sabemos que poupança é igual investimento, poupança externa não financia apenas

25 “La Experiencia Populista de Distribuición de Renda” (Canitrot, 1975). 
investimento? Não, novamente. Pode financiar tanto investimento quanto consumo, mas geralmente financia consumo, já que, como vimos, aprecia o câmbio, e o câmbio valorizado estimula o consumo. Na verdade, poupança externa é uma expressão marota. Ou marotamente usada, como acontece com muitos outros termos nesta ciência tão ideológica mas tão orgulhosa de não sê-lo como é a ciência econômica. Poupança externa é simplesmente déficit em conta corrente, mas, como pode ser financiada por investimentos diretos, é facilmente confundida com estes.

Quando o déficit em conta corrente (ou a poupança externa) é financiado por investimentos diretos temos, sem dúvida, uma situação mais favorável do que quando financiado por empréstimos, mas nem por isso a poupança externa é benéfica. Se o país tiver grandes projetos de investimento, como era o caso dos Estados Unidos no século XIX, o financiamento do déficit em conta corrente com investimento direto poderá ser benéfico. Se, entretanto, este não for o caso, e o investimento direto acabar financiando consumo, só aumentará a dívida do país, já que o estoque de capitais externos no país é também dívida - é dívida patrimonial servida por remessa de dividendos ao invés de remessa de juros. ${ }^{26}$

No caso do Brasil, o investimento direto externo era cerca de US\$2 bilhões por ano no início da década, e passou a ser os mesmos US\$2 bilhões, mas por mês, no governo Fernando Henrique, mas nem por isso a taxa de acumulação de capital e a taxa de crescimento do país aumentaram. A poupança externa foi compensada pela despoupança interna, dado que a poupança doméstica caiu com a valorização do câmbio e o conseqüente aumento da propensão média a consumir, de forma que a taxa de investimento não aumentou e o país permaneceu semi-estagnado, crescendo menos de 1 por cento per capita no período.

\section{ELITES ALIENADAS}

Cabe, porém, uma terceira questão encadeada. Se o erro de agenda, privilegiando o combate da inflação e não o desequilíbrio externo, foi resultado do Segundo Consenso de Washington, por que o Brasil aceitou sem crítica esse consenso? Minha resposta a esta pergunta só pode ser uma: porque não apenas as autoridades econômicas, mas, mais geralmente, as elites brasileiras demonstraram-se alienadas, incapazes de definir e defender o interesse nacional. A política econômica no governo Fernando Henrique foi desastrosa na medida em que refletiu a incapacidade das elites brasileiras de pensar por conta própria e de criticar o Segundo Consenso de Washington.

Um país, quando realiza sua revolução capitalista, tende também a realizar sua

\footnotetext{
${ }^{26} \mathrm{O}$ total da dívida financeira e da dívida patrimonial do país menos reservas e investimentos e empréstimos ao exterior feitos pelo país é seu passivo externo líquido. Como as duas últimas parcelas são pouco importantes nos países em desenvolvimento econômico, o passivo externo líquido corresponde à dívida total externa menos reservas.
} 
revolução nacional. Através da primeira, a apropriação do excedente passa a ocorrer principalmente através do mercado, as instituições passam a garantir a propriedade e os contratos, e a acumulação de capital e a incorporação de progresso técnico tornam-se processos intrínsecos ao sistema econômico. Através da segunda, as decisões do governo passam a responder aos interesses nacionais, ou seja, aos interesses do trabalho e do capital nacionais. O Brasil completou sua revolução capitalista nos anos 1960, mas, no início dos anos 1980, quando começa sua grande crise, sua revolução nacional, ainda que houvesse avançado, não se havia completado. Interrompida pela crise da dívida externa e a crise fiscal do Estado, a revolução nacional continuou paralisada nos anos 90 . Os brasileiros continuavam vítimas do complexo de inferioridade colonial, ou da "fracassomania" de que nos falou Albert Hirschman.

Este é um problema cultural difícil de ser solucionado, especialmente enquanto as elites brasileiras se revelarem incapazes de se identificar com a própria nação. Minha impressão, entretanto, é a de que os pobres, ou o povo, têm avançado nesta matéria. São capazes de absorver a cultura estrangeira e incorporá-la criativamente na nossa própria cultura. $\mathrm{O}$ caso do nosso mais bem-sucedido bem cultural de exportação - a música popular brasileira - é uma indicação positiva nesse sentido. Os níveis crescentes de educação, atingindo hoje a massa da população brasileira, contribuem na direção de uma maior capacidade de valorizar o que é nosso. Entretanto, enquanto o povo avança, ainda que lentamente, na recusa do complexo de inferioridade colonial, nossas elites retrocederam dramaticamente nos últimos 20 anos.

As elites cafeeiras do Oeste paulista, além de iniciar a Revolução Capitalista brasileira, na segunda metade do século XIX, contribuíram de forma significativa no sentido de definir a identidade nacional. A semana de arte moderna, de 1922, e o Manifesto Pau Brasil foram marcos dessa mudança. Em seguida, a elite industrial paulista e a tecnocrática do Rio de Janeiro, reunidas em torno dos governos Vargas e Kubitschek, promoveram um enorme avanço na afirmação dos interesses nacionais. ${ }^{27}$ A Revolução Nacional avançou a passos largos a partir de então. E, apesar dos pesares, continuou a avançar durante o regime militar. Entretanto, quando o Estado desenvolvimentista, que fora tão bem-sucedido em promover o desenvolvimento nacional, entrou em crise nos anos 80 , nossas elites perderam rumo. Nesse momento, a ideologia neoliberal senão ultraliberal tornara-se dominante em Washington e Nova York, e se transformava em ofensiva sobre os países em desenvolvimento. Dada a crise que estes países viviam, especialmente na América Latina, os arautos das novas ideologias encontraram aqui campo fértil. Mais fértil do que nos próprios países ricos. Nos anos 1990, nossas elites, que desde os anos 1930 haviam aumentado significativamente sua capacidade de identificar e de defender o interesse nacional, retrocederam de forma dramática. Diante da crise da estraté-

\footnotetext{
${ }^{27}$ Não falo em elites tecnocráticas cariocas, mas do Rio de Janeiro, porque os membros dessa elite provinham de todos os Estados do país.
} 
gia anterior de desenvolvimento, ao invés de pensar uma nova estratégia que consultasse os interesses nacionais, simplesmente se renderam à ofensiva ideológica vinda do Norte.

Em seu último livro, Em Busca de Novo Modelo, Celso Furtado voltou a dar ênfase a um problema que se tornou central para as classes médias e altas brasileiras pelo menos desde os anos 1960: a busca desenfreada de imitar os padrões de consumo dos países centrais, particularmente dos Estados Unidos. Nesse livro, Furtado volta às raízes do desenvolvimento econômico: a revolução capitalista e a revolução científica. A interação entre esses dois processos deve ser buscada, de um lado, na intuição de Galileu de que a natureza seria racional e poderia ser reduzida a esquemas geometrizáveis; de outro, ao processo de acumulação capitalista que torna a racionalidade instrumental dominante. Neste processo, porém, a industrialização tardia de países como o Brasil foi muito diferente da que ocorreu nos países hoje desenvolvidos, porque enquanto nestes a inovação e a difusão combinam-se para responder às próprias necessidades das sociedades, naqueles a difusão é marcada pela tentativa de imitação por parte das elites — as classes altas e as médias - dos padrões de consumo do centro.

Esta reprodução dos padrões de consumo vai continuar a determinar hoje as duas tendências centrais das economias periféricas: (1) a propensão ao endividamento externo e (2) a propensão à concentração social da renda. Ambos os processos têm como matriz a alta propensão a consumir das elites brasileiras em sua ansiedade em reproduzir o consumo central. Comparando o Brasil com a Índia, ele nos apresenta dados poderosos em favor do seu argumento. Embora a Índia tenha uma renda por habitante que é um quinto da brasileira, sua taxa de poupança é consideravelmente maior do que a do Brasil. Como se explica isto? Porque a renda é muito mais concentrada no Brasil nas classes altas e médias do que na Índia. Neste país os 20 por cento mais ricos controlam uma renda quatro vezes maior do que os 20 por cento mais pobres, enquanto que no Brasil essa relação é 32!

A busca da reprodução dos padrões de consumo norte-americanos está na raiz seja da concentração de renda, seja da baixa taxa de poupança: desta, dada a própria natureza da tentativa; daquela, na medida em que a demanda para os bens de consumo de luxo produzidos depende dessa concentração. A primeira relação parece-me indiscutível. Já a segunda, eu creio que perdeu grande parte da sua validade. Nos anos 1960 e 1970, em um momento em que o acesso a muitos dos bens de consumo de luxo estava restrito à classe média e à classe alta, a concentração de renda já existente era reforçada pelo tipo de bem produzido. Hoje, entretanto, quando as empresas buscam desesperadamente atingir os pobres com seus bens e serviços, eu creio que o agravamento da concentração de renda, que continua a ocorrer, deve ser buscado antes no enfraquecimento relativo dos pobres em defender seus interesses, e no tipo de desenvolvimento tecnológico, que aumentou a demanda de trabalho qualificado, enquanto que diminuía o de trabalho não-qualificado.

Mais importante na análise de Furtado, entretanto, é o fato de que as classes beneficiadas com essa concentração não se revelam à altura de seu papel de elites. 
Ao copiarem os padrões de consumo norte-americanos, não poupam para investir, e endividam o país no exterior. A acusação de prática do populismo econômico, que essas classes usam para atacar os políticos populares, é indevida porque é o consumo delas e não o dos pobres que leva ao déficit público e, principalmente, ao populismo cambial: a valorização artificial do câmbio, em nome do combate da inflação, para facilitar o consumo de bens e serviços com considerável componente importado. Não são os pobres que adquirem bens importados, nem que viajam para o exterior.

Celso Furtado concentra assim sua análise no consumo das elites. Estou de acordo, mas seria ainda mais severo. É patético o fracasso político das elites atuais. Alienadas em um grau impensável, fracassam na sua missão de dirigir o país. Ao reproduzirem os padrões de consumo do centro - inclusive em suas tristes residências "neoclássicas" que constituem uma irrisão para a grande arquitetura brasileira - reproduzem também, de forma acrítica, a ideologia externa. Ao invés de definir, caso a caso, qual o interesse nacional, e defendê-lo, dedicam-se apenas ao "confidence building". O que lhe interessa é saber o que os estrangeiros pensam do Brasil, não o que o Brasil pensa sobre seu futuro.

\section{O RISCO DA CRISE INTERNA}

A crise de balanço de pagamentos poderá ser agravada ou superada dependendo da forma que o governo enfrentar o problema interno. No plano externo, o governo fez o mais importante, logrou - logo que a crise se tornou clara - um novo acordo com o FMI. A perda de confiança dos credores estrangeiros não foi superada, já que a renovação dos créditos de longo prazo e das linhas de crédito comerciais de curto prazo das empresas brasileiras continua suspensa, mas o governo e o FMI fizeram o que era obrigação de ambos no momento. Por outro lado, a iniciativa do presidente Fernando Henrique de conversar com os candidatos à presidência sobre esse acordo, obtendo deles sua concordância (o que não significava, naturalmente, que concordassem com a política econômica que tornou o acordo necessário) era o que melhor poderia ter feito no plano político. O importante agora é impedir que a crise externa se transforme em crise interna, uma passando a realimentar a outra. No momento em que escrevo, em dezembro de 2002, as empresas endividadas em dólares enfrentavam dificuldade em rolar suas dívidas, não apenas porque os credores não renovam seus empréstimos, afetando sua liquidez, mas também porque a taxa de câmbio subiu e provocou redução de seus lucros senão prejuízos. Por outro lado, os empresários naturalmente pessimistas diante dos fatos, reduziram seus investimentos.

Diante desses fatos, é necessário que o governo assegure a devedores e especuladores que usará sem hesitação suas reservas para manter a taxa de câmbio em um nível que leve ao equilíbrio da conta corrente. Certamente não é de R \$2,40 por dólar, mas também não é maior que a taxa atual, de aproximadamente $\mathrm{R} \$ 3,50$. Em lugar de uma meta de inflação, devemos, conservando flutuação do câmbio, ter 
em vista um nível de taxa de câmbio real para garantir exportadores e devedores. Imagino que esse nível, que deveria ser assegurado através das medidas clássicas de uma flutuação "suja", seria de cerca de R \$ 3,00 reais por dólar. No momento, entretanto, seria inclusive razoável que as autoridades monetárias deixassem que a taxa de câmbio suba para próximo de $\mathrm{R} \$ 3,50$ : tal overshooting deverá desestimular as saídas e estimular as entradas (já que os agentes econômicos saberão - ou desconfiarão - racionalmente que a taxa de equilíbrio, para a qual a taxa mais afinal voltará, é menor). Mas a taxa de câmbio não deverá subir além desse nível para se evitar uma debilidade adicional das empresas endividadas.

Por outro lado, dada a suspensão da rolagem da dívida e as previsões de déficit em conta corrente e de amortizações, a expectativa é de que o país, cujas reservas líquidas estão em torno de US\$ 23 bilhões, termine o ano com reservas líquidas próximas de zero. O problema que se coloca para o governo é saber até que ponto deve usar suas reservas para manter o câmbio no nível que estimo de equilíbrio, ou se deixa que ocorra o overshooting do câmbio. Em qualquer hipótese, a herança que o atual governo deixa para o próximo é de crise. O default só será evitado se o FMI liberar o uso de seus recursos, que em princípio não devem ser usados, até o momento em que um aumento ou a perspectiva de um aumento do superávit comercial leve os credores a renovar suas linhas de crédito. Williamson realizou um cuidadoso estudo das perspectivas de default do Brasil, e chegou à conclusão de que há, de um lado um elemento de pânico por parte do mercado, que não se justifica pelas declarações dos candidatos; de outro, a prática de elevadas taxas de juros conspira para manter a dívida interna em elevação e a economia como um todo sob perigo, já que o superávit primário tenderá a ser de R \$53 bilhões em 2003 contra um total de juros internos de R $\$ 176$ bilhões. Tudo, afinal, dependerá, de um lado, de como será o comportamento do novo governo na área fiscal e monetária, e, de outro, dos credores externos. ${ }^{28}$

$\mathrm{Na}$ área interna, o problema fundamental é o de enfrentar o pessimismo dos empresários e reverter a queda dos investimentos que está provocando taxas de desemprego recordes. Preocupado com uma elevação da taxa de inflação que é temporária, decorrente da desvalorização cambial, o governo insiste em continuar aumentando a taxa de juros nominal. O próximo governo, assim que recupere o crédito internacional, deverá começar a reduzir a taxa de juros de forma determinada. No documento Bresser-Pereira e Nakano (2002a) demonstramos que a taxa de juros básica paga pelo Banco Central, ao contrário do que se afirmava, não é altíssima devido à classificação de risco do Brasil. Essa elevação é explicada por um "conservadorismo monetário" excessivo praticado há mais de dez anos pelo Banco Central. Muitos países, com classificações de risco iguais ou piores do que a do Brasil, apresentam, consistentemente taxas de juros básicas duas a três vezes menores. Entendíamos, no início de 2002, que a redução da taxa de juros para cerca da metade do nível atual deveria ser adotada no próximo governo, dentro de

${ }^{28}$ Ver Williamson (2002). 
um quadro de mudança de regime de política econômica, para, assim, se poder retomar o desenvolvimento. Dada, porém, a nova crise de confiança externa e recessão interna, que ameaçam a solvabilidade das empresas, o governo Fernando Henrique Cardoso deveria começar imediatamente a baixar a taxa de juros.

A alternativa "ortodoxa", entretanto, continuou a ser praticada pelo Banco Central até o final do governo Cardoso. Ao invés de baixar ou manter o Banco Central continuou a aumentar a taxa de juros, para tentar reduzir o câmbio e a inflação. O próprio FMI pressionou o governo brasileiro nesse sentido quando da assinatura do último acordo. Isto seria razoável caso a crise de balanço de pagamentos fosse resultado de excesso de demanda. Não é. É resultado de excesso de dívida e da existência de déficit em conta corrente ainda muito alto, embora com tendência à baixa. Elevar a taxa de juros em uma situação desse tipo foi o que fez a Nova Zelândia, em 1997, como resposta à crise dos países asiáticos que se refletia fortemente naquele país. O resultado foi desastroso, levando inclusive o partido do governo a perder as eleições seguintes. A Austrália, enfrentando o mesmo problema, fez o oposto - reduziu a taxa de juros e estimulou a economia voltando-se para o mercado externo. Foi um grande êxito e o governo reelegeu-se.

A diferença daqueles países para o Brasil é que suas economias não eram tão frágeis internacionalmente. Mas isto não significa que devamos, diante da crise de balanço de pagamentos, nos amedrontar. Ao contrário, os perigos que enfrentamos são maiores, exigindo maior determinação e coragem da nossa parte. O essencial, agora, é fortalecer as empresas e os bancos nacionais. Estes estão sólidos graças à competente reestruturação realizada através do PROER e à boa qualidade da sua administração, mas não há solidez que resista à crise externa acoplada à interna. ${ }^{29}$

Ao mesmo tempo, o novo governo precisa aprofundar seu ajuste fiscal. Da mesma forma que certa ortodoxia incompetente certamente proporá elevar juros, outra "heterodoxia" igualmente incompetente proporá gastar mais para aumentar a demanda. Seria um erro igualmente grave. Quando o FMI assinou novo acordo com o Brasil, em agosto de 2002, contentou-se com um superávit primário de 3,75 por cento. Naquele momento vários economistas e homens públicos brasileiros lamentaram a "dureza" do FMI, que "impediria o desenvolvimento do Brasil". Este tipo de "keynesianismo" equivocado não honra o grande economista inglês. É apenas sua tradução vulgar, populista. ${ }^{30}$

Keynes defendia, sem dúvida, uma política fiscal ativa quando o país estivesse entrando em uma recessão. Hoje, este tipo de política é universalmente aceito, apesar de toda a onda neoclássica contra o pensamento de Keynes. Entretanto,

\footnotetext{
${ }^{29}$ O PROER, embora muito criticado pela oposição porque obviamente teve um custo, foi um programa competente do Banco Central que logrou sanear o sistema financeiro brasileiro em 1996. Os bancos de varejo insolventes foram reestruturados, e os depósitos bancários, preservados. Em compensação, os acionistas dos bancos reestruturados perderam seu controle e sua propriedade (dado que o patrimônio líquido dos bancos havia se tornado negativo).

${ }^{30}$ Ver Bresser-Pereira e Dall'Acqua (1991).
} 
Keynes sempre defendeu que se o país partia de uma situação de equilíbrio fiscal, deveria voltar, imediatamente após a adoção da política fiscal ativa, ao equilíbrio fiscal temporariamente perdido. Para ele era inadmissível um déficit público crônico. Além disso, Keynes supunha que a recessão, e a conseqüente tendência à deflação, resultavam de uma propensão a investir provisoriamente rebaixada devido à insegurança quanto ao futuro dos investidores em ativos reais ou dos consumidores.

Depois de Keynes, uma segunda coisa ficou clara em relação ao déficit público, à demanda agregada, e à inflação. Esta pode ocorrer em situação de insuficiência crônica de demanda e de déficit público também crônico. Nesses casos, a baixa propensão a investir dos empresários é conseqüência do déficit público e da inflação que levam os produtores a formar perspectivas negativas em relação ao futuro. Ora, nestas circunstâncias a melhor política de estímulo à demanda agregada não é aumentar o gasto fiscal mas diminuí-lo. Nestas circunstâncias, só uma política dessa natureza será capaz de restabelecer a confiança dos empresários e de levá-los a retomar os investimentos, porque a expectativa (racional) dos agentes econômicos é a de que a continuidade do déficit público levará mais cedo ou mais tarde à crise fiscal e financeira. O mesmo raciocínio se aplica para os investidores e credores internacionais. Considerando-se estas expectativas, seria adequado que o novo governo, enquanto estivesse providenciando a baixa gradual dos juros, procurasse aumentar o superávit primário para 5\% do PIB. Sei que não é fácil nem agradável, mas jamais recuperaremos o crédito externo e a confiança dos empresários internos se afrouxarmos a política fiscal. Pelo contrário, precisamos endurecê-la.

$\mathrm{O}$ compromisso informal com uma taxa de câmbio real igual ou um pouco superior a R \$3,00, a baixa gradual mas firme da taxa de juros e o aprofundamento do ajuste fiscal manterão a economia no próximo ano desaquecida, crescendo aproximadamente à mesma taxa deste ano $(0$ por cento de crescimento da renda por habitante), mas, em compensação, poderemos esperar, dentro de um prazo razoável, a volta do crédito externo e da confiança interna.

Mais do que isto, tornar-se-á possível, afinal, que o país cresça sem o limite da "restrição externa”. Ou seja, dada a taxa de câmbio real mais alta, será possível que aumente o PIB sem que se produza um déficit em conta corrente que obrigue as autoridades monetárias a restringir o crescimento. No passado, usava-se a expressão "restrição externa" para significar a falta de acesso aos mercados financeiros internacionais. Note-se, portanto, que estou usando essa expressão em um sentido quase oposto. Foi o Segundo Consenso de Washington, e portanto, a falta de restrição nesse sentido que nos levou à crise atual. Dados os índices elevados de endividamento da economia brasileira, esta só voltará a crescer de forma sustentada, sem restrição externa, se a sua taxa de câmbio for a de equilíbrio da conta corrente.

\section{CONCLUSÃO}

O governo Fernando Henrique Cardoso termina em um quadro de crise de balanço de pagamentos. O presidente foi extremamente bem-sucedido quando, co- 
mo ministro da Fazenda, liderou o Plano Real em 1994, e estabilizou os preços. A política que sua equipe econômica adotou nos anos seguintes, porém, ao invés de completar a estabilização macroeconômica, levou-a a deteriorar-se. A razão imediata deste mau resultado foi o governo ter estabelecido como sua principal agenda econômica a garantia da estabilidade de preços, ao invés de compreender que este objetivo estava razoavelmente garantido, e tratar de priorizar o equilíbrio das contas externas.

Os primeiros quatro anos de governo terminaram em crise cambial seja porque o ajustamento fiscal insatisfatório e as altas taxas de juros impediram o equilíbrio fiscal, seja porque a taxa de câmbio sobrevalorizada levou a grandes déficits em conta corrente, e o grande aumento da dívida externa e do passivo total líquido do país. O segundo período do governo foi inaugurado com uma corajosa e bemsucedida flutuação do real, mas terminou igualmente em crise de balanço de pagamentos. Em seguida à flutuação do câmbio a taxa de juros, que havia sido elevada no momento da desvalorização, foi sendo reduzida pelo Banco Central, enquanto as metas fiscais eram atingidas graças principalmente ao aumento dos impostos. A taxa de juros básica, entretanto, mantinha-se em nível muito superior ao que justificariam as classificações de risco do Brasil. Não obstante, quando, no início de 2001, diante do agravamento da crise da Argentina, e do fato de a economia brasileira dar modestos sinais de aquecimento, a taxa de câmbio subiu para próximo de $\mathrm{R} \$ 3,00$, o Banco Central cometeu o erro de novamente priorizar o combate à inflação em prejuízo das contas externas. Elevou a taxa de juros e vendeu dólares no mercado para impedir que a taxa de câmbio se estabilizasse nesse nível. Com isto, voltava-se à política de 1995-98, de dar toda prioridade ao combate à inflação.

Existe, portanto, uma possibilidade concreta de os credores obrigarem o país ao default. Entretanto, a solvência da economia brasileira vinha melhorando desde a bem-sucedida flutuação do câmbio em janeiro de 1999, graças ao aumento das exportações e do superávit comercial, de forma que, adotada uma política que aprofunde o ajuste fiscal enquanto baixe a taxa de juros interna e evite que o real venha a se reavaliar, o país provavelmente evitará o default.

A razão principal para esse comportamento irracional foi ter o governo aceito de forma acrítica o Segundo Consenso de Washington, segundo o qual países altamente endividados, como o Brasil, poderiam resolver seus problemas recorrendo a poupança externa, ou seja, a mais endividamento. Esta política interessava aos países ricos, que assim viam justificados grandes superávits comerciais, interessava aos bancos internacionais que podiam emprestar a elevadas taxas de juros aos países emergentes, e interessava às autoridades locais na medida em que ali havia um elemento populista - o populismo cambial - suficientemente disfarçado para contar com o apoio do próprio FMI. Este, nos termos do Segundo Consenso de Washington, ao invés de adotar uma "hard budget constraint", adotou claramente uma "soft current account constraint", o que interessava a seus principais acionistas tanto no plano comercial quanto financeiro.

A crise de balanço de pagamentos hoje em curso provavelmente não teria ocorrido se não fosse o novo aumento da taxa de juros em 2001 e o uso de US\$28 
bilhões para evitar a depreciação do real. Esse novo erro de política econômica acentuou a fragilidade financeira do país. Entretanto, é razoável prever a mudança das perspectivas dos credores internacionais em relação à nossa capacidade de manter o serviço da dívida. Esta mudança ocorrerá se a meta contratada com o FMI de 3,75 por cento do PIB de superávit primário continuar a ser alcançada, se a depreciação do real, ocorrida nos últimos meses, elevando a taxa de câmbio para cerca de $\mathrm{R} \$ 3,00$, for mantida aproximadamente nesse nível, de forma a se consolidar a tendência, hoje já evidente, de aumento do superávit comercial, e se o novo presidente revelar-se confiável para com os credores internacionais.

A atual crise de balanço de pagamentos está sem dúvida relacionada com as eleições. Ao aumentarem as expectativas de vitória da oposição, a crise de confiança, que estava latente, aflorou. Há nela um elemento de pânico ou de efeito-manada, mas não há dúvida de que ela reflete uma política gravemente equivocada por parte da equipe econômica chefiada pelo ministro Pedro Malan nestes oito anos de governo Fernando Henrique Cardoso. Nestes oito anos, a equipe econômica e as elites que ela representa erraram ao adotarem ou apoiarem uma política de altos juros, que impede o investimento enquanto aprofunda o endividamento público, e de câmbio baixo, que produz a felicidade no curto prazo às custas da crise cambial anunciada.

Por que o governo do Brasil, aliás como o da grande maioria dos países em desenvolvimento - as grandes exceções são a China, a Índia, e, na América Latina, o Chile - adotou tal política? Principalmente porque suas elites revelaram-se particularmente alienadas. Da mesma forma que essas elites reproduzem os padrões de consumo do centro, como Celso Furtado voltou a ressaltar com grande veemência em seu último livro, eu adiciono que elas reproduzem as idéias do centro, estando as duas reproduções intrinsecamente relacionadas.

Só será possível sair desse impasse na medida em que as elites brasileiras percam poder para a sociedade civil e, mais amplamente, para as camadas populares. Furtado percebe este fato quando afirma que "o ponto de partida do processo de reconstrução que temos de enfrentar deverá ser uma participação maior do povo no processo de decisão", ${ }^{31}$ mas em seguida, contraditoriamente, ele manifesta sua esperança de que os intelectuais ajam como uma vanguarda para evitar que a mancha de irracionalidade se alastre. Não creio que os intelectuais tenham essa capacidade ou mesmo essa virtude. Só vejo esperança para o Brasil na medida em que a democracia se aprofunde, que círculos cada vez mais amplos da população se envolvam no debate público, tanto ao nível local e setorial como ao nível nacional, estabelecendo assim limites para a alienação das classes médias e altas. Em outras palavras, na medida em que a atual democracia de elites seja, afinal, substituída por uma democracia de sociedade civil, ou de opinião pública, na qual o debate público generalizado se transforme em fator determinante das principais políticas

${ }^{31}$ Furtado (2001: 36). 
públicas adotadas pelo país. ${ }^{32}$ Não chegamos ainda a esse estágio de governança, mas, se nosso desenvolvimento econômico tem sido decepcionante nos últimos dois decênios, o mesmo não se pode afirmar do desenvolvimento político.

Não obstante toda a força da ideologia globalista, que insiste na tese da crescente debilitação dos Estados nacionais, estou convencido de que poderemos afinal afirmar nosso interesse nacional. $\mathrm{Na}$ globalização, os Estados nacionais são mais interdependentes, mas precisam ser cada vez mais fortes. Globalização é competição entre empresas nacionais (convencionalmente chamadas de multinacionais) ao nível mundial. O que os governos dos países ricos fazem é defender o capital e o trabalho nacionais - ou seja, suas empresas nacionais. O Brasil não tem alternativa senão fazer o mesmo.

\section{REFERÊNCIAS BIBLIOGRÁFICAS}

BALL, Laurence (2000) "Policy Rules and External Shocks", NBER Working Paper 7910, September 2000, http://www.nber.org/papers/w7910.

BRESSER-PEREIRA, Luiz Carlos (1991a) "A Crise da América Latina: Consenso de Washington ou Crise Fiscal?”. Pesquisa e Planejamento Econômico 21(1), abril 1991.

BRESSER-PEREIRA, Luiz Carlos (1991b) A Crise do Estado. São Paulo: Editora Nobel.

BRESSER-PEREIRA, Luiz Carlos (1997) “As Três Formas de Desvalorização Cambial” (1997). Revista de Economia Política 17(1), janeiro 1997: 143-146.

BRESSER-PEREIRA, Luiz Carlos (2000) "Da Política de Elites à Democracia de Sociedade Civil”. In João Paulo dos Reis Velloso, org. (2000): 517-538.

BRESSER-PEREIRA, Luiz Carlos (2001) "Self-Interest and Incompetence". Journal of Post Keynesian Economics 23(3), Spring 2001: 363-373.

BRESSER-PEREIRA, Luiz Carlos e DALL'ACQUA, F. (1991) “Economic Populism x Keynes: Reinterpreting Budget Deficit in Latin America". Journal of Post Keynesian Economics, 14(1), outono 1991. Traduzido para o português em Bresser-Pereira, org. (1991).

BRESSER-PEREIRA, Luiz Carlos e NAKANO, Yoshiaki (2002a) "Uma Estratégia de Desenvolvimento com Estabilidade”. Revista de Economia Política, 21(3) julho 2002:146-177.

BRESSER-PEREIRA, Luiz Carlos e NAKANO, Yoshiaki (2002b) "Economic Growth with Foreign Savings?” Revista de Economia Política, 22(2) abril 2003.

BRESSER-PEREIRA, Luiz Carlos, MARAVALL, José María e PRZEWORSKI, Adam (1996) Reformas Econômicas em Novas Democracias. São Paulo: Editora Nobel, 1996. Publicado originalmente em inglês, 1993.

BRESSER-PEREIRA, Luiz Carlos, org. (1991) Populismo Econômico, São Paulo: Nobel, 1991.

CANITROT, Adolfo (1975) “A Experiência Populista de Redistribuição de Renda”. In Bresser-Pereira, org. (1991) Populismo Econômico. São Paulo: Editora Nobel. Originalmente publicado em Desarrollo Económico, 1975.

COAKLEY, J., KULASI, F. e SMITH, R. (1996) "Current Account Solvency and the Feldstein-Horioka Puzzle, The Economic Journal, 106, 1996: 620-627. Citado em Zerbini (2002).

COHEN, Daniel (1994) "Growth and External Debt”, in Van der Ploeg, Frederick (ed.), The Handbook of International Macroeconomics, Cambridge.

FURTADO, Celso (2002) Em Busca do Novo Modelo. São Paulo: Editora Paz e Terra.

\footnotetext{
${ }^{32}$ Ver Bresser-Pereira (2000).
} 
MARAVALL, José María (1996) "Política e Políticas: Reformas Econômicas na Europa Meridional”. In Bresser-Pereira, Maravall e Przeworski (1996): 83-132.

PATILLO, C., POIRSON, H. e RICCI, L. (2002) “External Debt and Growth”, IMF Working Paper, no. $02 / 69$.

REIS VELLOSO, João Paulo, org. (2000) Brasil 500 anos. Futuro, Presente, Passado. Rio de Janeiro: Editora José Olympio.

RODRIK, Dani (1998) "Who Needs Capital — Account Convertibility?", in Essays in International Finance, 207. Princeton University.

ROCHA, Fabiana e Maria Beatriz ZERBINI (2002) “Using Panel Structure to Discuss the FeldsteinHorioka Puzzle in Developing Countries”. São Paulo: Departamento de Economia da Faculdade de Economia e Administração da USP, maio 2002. Cópia.

SIMONSEN, Mario H. e CYSNE, Rubens P. (1995), Macroeconomia. São Paulo: Editora Atlas.

SINN, S. (1992) "Saving-investment Correlations and Capital Mobility: On the Evidence from Annual Data”. Economic Journal, setembro, 1992, n 102: 1162-1170. Citado em Rocha e Zerbini (2002).

TAYLOR, John B. (1993) "Discretion versus Policy Rules in Practice". Carnegie-Rochester Series on Public Policies 39: 195-214.

TAYLOR, John B. (2001) “The Role of the Exchange Rate in Monetary-Policy Rules”, American Economic Review, 91(2), May 2001: 263-267.

WILlIAMSON, John (1990) "What Washington Means by Policy Reform": 7-38 e "The Progress of Policy Reform in Latin America": 353-420. In Williamson, John, org. (1990) Latin American Adjustment: How Much Has Happened?. Washington: Institute for International Economics.

WILLIAMSON, John (2002) “Is Brazil Next?" Washington, DC: Institute for International Economics, International Economics Policy Briefs, PB02-7, agosto 2002. 